
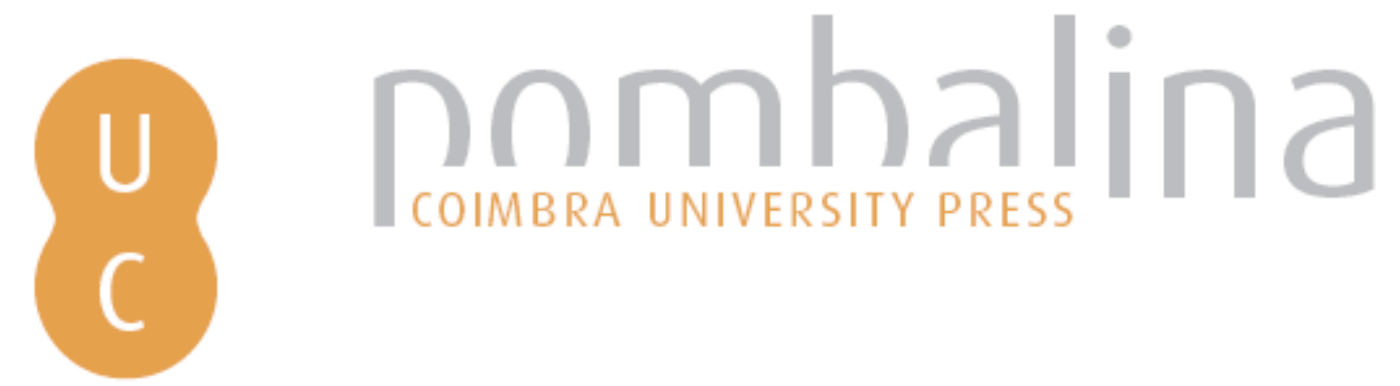

\title{
Turismo e desenvolvimento dos territórios insulares: apontamentos para uma geografia do turismo de Cabo Verde
}

\author{
Autor(es): $\quad$ Cunha, Lúcio; Jacinto, Rui \\ Publicado por: Imprensa da Universidade de Coimbra \\ URL \\ persistente: URI:http://hdl.handle.net/10316.2/37381 \\ DOI: $\quad$ DOI:http://dx.doi.org/10.14195/978-989-26-0754-2_20 \\ Accessed : $\quad$ 26-Apr-2023 14:13:41
}

A navegação consulta e descarregamento dos títulos inseridos nas Bibliotecas Digitais UC Digitalis, UC Pombalina e UC Impactum, pressupõem a aceitação plena e sem reservas dos Termos e Condições de Uso destas Bibliotecas Digitais, disponíveis em https://digitalis.uc.pt/pt-pt/termos.

Conforme exposto nos referidos Termos e Condições de Uso, o descarregamento de títulos de acesso restrito requer uma licença válida de autorização devendo o utilizador aceder ao(s) documento(s) a partir de um endereço de IP da instituição detentora da supramencionada licença.

Ao utilizador é apenas permitido o descarregamento para uso pessoal, pelo que o emprego do(s) título(s) descarregado(s) para outro fim, designadamente comercial, carece de autorização do respetivo autor ou editor da obra.

Na medida em que todas as obras da UC Digitalis se encontram protegidas pelo Código do Direito de Autor e Direitos Conexos e demais legislação aplicável, toda a cópia, parcial ou total, deste documento, nos casos em que é legalmente admitida, deverá conter ou fazer-se acompanhar por este aviso.

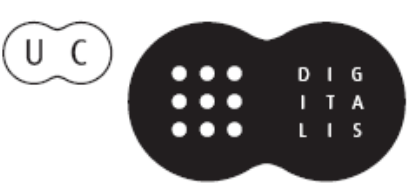


LÚCIO CUNHA, RUI JACINTO

CEGOT, Universidade de Coimbra

TURISMO E DESENVOLVIMENTO DOS TERRITÓRIOS

INSULARES. A PONTAMENTOS PARA UMA GEOGRAFiA

DO TURISMO DE CABO VERDE

\section{Introdução}

As condições naturais, em que se destacam o clima, a temperatura da água do mar, a geomorfologia e a paisagem, a amenidade social, o legado cultural e a progressiva qualificação da oferta, têm contribuído para afirmar Cabo Verde como um destino emergente entre os mercados turísticos internacionais. Esta dinâmica, que decorre do forte crescimento que o turismo conheceu no passado recente, confere ao setor uma posição central no processo de desenvolvimento do país, com manifestos impates na economia, na sociedade e no ambiente, transformando-o na última esperança de sobrevivência para muitas comunidades locais.

A projeção duma imagem positiva e a promoção do turismo deste pequeno país insular, assentam na valorização dos vários recursos disponíveis, tendo-se afirmado entre os principais ativos a tranquila qualidade das praias (Sal e Boavista), as paisagens ímpares que se desfrutam nas ilhas de relevo mais vigoroso (Fogo, Santo Antão, S. Nicolau e Santiago), a austera beleza e interesse ambiental dos seus parques naturais (Ilha do Fogo; Serra Malagueta) a par com a cultura ímpar materializada no modo de viver cabo-verdiano. As heranças e os traços, materiais e intangíveis, que a história e a geografia foram sedimentando, projetam a identidade dum povo, perpetuada na literatura e na música, em que se evocam e inscrevem as diferentes diásporas que fizeram de Cabo Verde e dos cabo- 
-verdianos territórios e pessoas abertos a múltiplos diálogos. Viajar nestes territórios é percorrer um vasto património em profunda mutação, locais densos de história, impregnados de reminiscências coloniais (Cidade Velha ou Chão Bom no Tarrafal), donde emana um cosmopolitismo contido (centro histórico do Mindelo ou o Plateau na Praia), onde sentimos palpitar uma vibrante cultura popular, tanto nos bairros e subúrbios dos dois principais aglomerados, como nas mais remotas áreas rurais.

O segmento de turismo dominante (sol-praia) tem como pólos essenciais as ilhas do Sal e da Boavista, onde se impõe com uma força esmagadora sobre os frágeis ecossistemas insulares, convivendo esta atividade, no restante arquipélago, em relativa harmonia, com a envolvente natural e humana. Abre-se, por esta razão, uma boa oportunidade para uma resposta atempada à forte pressão que a expansão do setor exerce sobre o ambiente, os recursos naturais e a ocupação do território, de modo a evitar utilizações abusivas e desregradas, bem como a perspetivar uma evolução sustentável que pressupõe, também, o salutar envolvimento das comunidades locais.

Sem esquecer as especificidades de cada uma das ilhas nem a importância crucial do turismo para o desenvolvimento de Cabo Verde, pretende-se com este texto participar no debate que urge aprofundar sobre os limites e condicionantes que os frágeis contextos naturais locais impõem a um modelo de desenvolvimento turístico do arquipélago que se espera equilibrado, ordenado e sustentável.

\section{Cabo Verde e o turismo insular: geografia, insularidade e turismo}

\subsection{Geografia e insularidade: constrangimentos e oportunidades}

A localização em latitude e longitude, as diferentes posições que ocupam no globo terrestre e os múltiplos fatores, globais e locais, determinam distintos diálogos entre a terra e o mar e criam condições únicas e mutantes que explicam a diversidade geográfica e as especificidades das relações estabelecidas entre o ser humano e o meio em cada espaço 
insular. As dinâmicas dos agentes terrestres e marítimos, associadas à evolução da ação humana e ao contexto geopolítico onde Cabo Verde se integra, influenciaram decisivamente, tanto as caraterísticas ambientais, económicas, sociais e culturais de cada uma das ilhas, como o processo histórico, político e a consequente integração internacional.

Os arquipélagos, como as áreas fronteiriças, são espaços fechados, circunscritos, em que a geografia impõe fortes constrangimentos, fragmenta o espaço, limita horizontes e potencia as vertentes materiais e intangíveis que caraterizam a condição insular. A descontinuidade do território e as duras condições impostas pelo mar e por outros elementos naturais são fatores críticos que limitam os recursos e condicionam a mobilidade, logo a distribuição das pessoas e das atividades. Estes aspetos, além de explicarem a peculiar ocupação e organização dos espaços insulares, foram decisivos para instalar, entre os seus naturais, uma permanente sensação de isolamento, um sentimento de nostalgia e um desejo de evasão que alguns apelidam de insularidade.

No último meio século foi produzido um amplo conhecimento geográfico sobre Cabo Verde, em que se destacam, sem caráter exaustivo ou pretensão de representatividade, os seguintes períodos, autores ou obras mais significativas:

- autores clássicos, cujos estudos de referência, elaborados na época colonial, incidiram sobre as ilhas do Fogo e de Santiago (Orlando Ribeiro, 1960; Maria Luísa F. Ribeiro, 1961; Ilídio do Amaral, 1964); - autores de ascendência local que, na senda dos claridosos, refletiram sobre a realidade mais telúrica do arquipélago e abordaram, através de estudos ou de forma ficionada, as temáticas da cabo-verdianidade (Manuel Lopes, 1956, 1959; Baltazar Lopes, 1947; António Carreira, 1982 e 1983; Manuel Veiga, 1998; Germano de Almeida, 2003);

- autores que integram uma nova e emergente geração de geógrafos cabo-verdianos, como os envolvidos na obra coletiva que aborda diferentes facetas da insularidade e da desertificação, designadamente temas como as paisagens (naturais, rurais e urbanas), os riscos naturais ou a educação ambiental (Cunha e Jacinto, 2011), onde assinam 
artigos que resumem teses de doutoramento ou mestrado ou o trabalho técnico no âmbito do ordenamento do território (José Maria Semedo; Judite Nascimento; Sílvia Monteiro; Sónia Vitória; Moisés Borges; Romualdo Correia; Carlos Tavares).

O conhecimento produzido neste âmbito é importante para compreendermos os processos de ocupação do espaço e de organização social e económica, assim como as dinâmicas sócio-territoriais, em que se evidenciam constrangimentos, oportunidades e aspetos fundamentais para interpretar Cabo Verde e perspetivar cenários para o seu desenvolvimento.

Durante quase dois milénios, Cabo Verde, as Ilhas Afortunadas como eram conhecidas na Antiguidade, permaneceram esquecidas:

"Só no fim da Idade Média, quando os progressos da arte de navegar conjuram um tipo de velame que permitisse a bolina, isto é, a navegação contra o vento, e o uso de instrumentos que dessem com algum rigor a posição dos lugares, as ilhas do oceano Atlântico foram definitivamente ocupadas pelo homem, que logo as incorporou no património geográfico da civilização ocidental"1 (Ribeiro, 1960: 19-20).

Para além da sua condição arquipelágica, Cabo Verde não foge às regras impostas pelo mar, pelo clima e por outros elementos naturais que influenciaram dinâmicas económicas, sociais e culturais, moldando um modo de vida que espelha a escassez de recursos que as populações sempre enfrentaram. Na fronteira da sobrevivência e à mercê duma geografia austera, o cabo-verdiano sobrevaloriza a natureza, o clima e os riscos que lhes andam associados, com destaque para a seca, a aridez e a ausência

1 "Modernamente, deu-se o nome de Ilhas Atlântidas, ou Macaronésia, ao conjunto dos arquipélagos que, em frente à costa do velho Mundo, se estendem de 15 a $40^{\circ}$ de latitude norte - Açores, Madeira, Selvagens, Canárias e ilhas de Cabo Verde, $15700 \mathrm{Km} 2$ de terras emersas, vinte e oito ilhas e dezassete ilhotas perdidas na imensidão das águas oceânicas. Macaronésia, do nome grego das Canárias, ou Ilbas Afortunadas; Ilbas Atlântidas, por a posição delas evocar vagamente a "Atlântida" de Platão, "diante da passagem a que chamam Colunas de Hércules. Designações, como tantas outras, tomadas hoje muito longe do sentido original." 
de chuva, condicionantes pesadas e estruturais para uma agricultura de subsistência e para a produção do milho, base da alimentação do povo e do seu imaginário cultural.

Em Cabo Verde, a mistura de pessoas com várias proveniências e culturas originou um quadro humano que compensou a precariedade da natureza e criou uma sociedade crioula em que impera amenidade e morabeza, traços matriciais da identidade cabo-verdiana. A originalidade destas marcas intangíveis e das paisagens naturais e humanas únicas e diferentes representam um valor, constituem uma oportunidade e um verdadeiro recurso explorado pelo turismo para alicerçar a estratégia de crescimento que tem registado.

Contudo, as exigências dum setor fortemente consumidor de todo o tipo de recursos (alimentação, água, energia, materiais de construção civil), responsável por uma elevada "pegada ecológica", associadas às dificuldades do país (de configuração geográfica, logísticas, infra-estruturais, etc.) impõem limites à expansão dum setor que tem de conviver, de modo compatível, com um ambiente natural e humano tão frágil como o apresentado por Cabo Verde.

\subsection{Insularidade e turismo: a condição insular como recurso turístico}

A insularidade tem manifestações múltiplas, assumindo na versão cabo-verdiana uma dimensão tanto "geográfica como climática, histórica como política, antropológica como existencial" que resulta, segundo alguns, "do relacionamento do sujeito (...) com o espaço da ilha". Desta conjugação emana "o sentimento de solidão, de nostalgia que o ilhéu experimenta face ao isolamento e aos limites da fronteira líquida que o separa do mundo, criando-se um espaço de angústia e de ansiedade". Para outros, "a insularidade da crioulidade extravasa o sentimento de solidão e de nostalgia, emergente do acanhado espaço geográfico das ilhas, para incorporar outros aspetos resultantes tanto da dialética entre a imensidade do mar arquipélago e a pequenez das ilhas retalhadas que as ondas "afogam e afagam", como também entre a grandeza do sonho ilhéu que não se conforma com 
a medida da ilha e os problemas sociais, políticos e culturais de que as mesmas têm sido palco" (Veiga, 1998: 9).

As caraterísticas materiais próprias do isolamento acabam por envolver numa neblina de curiosidade, mistério e encantamento estes pedaços de terra perdidos no mar, impregnando as ilhas de mistério e de incerteza, e rodeando-as duma áurea que não deixa indiferentes tanto ilhéus como continentais. Os espaços insulares sempre exaltaram o imaginário e exerceram um fascínio especial a quem os observa do exterior, alimentado por inúmeros livros de aventuras e por todo o tipo de literatura de viagens, escritos ao longo dos tempos, por sucessivas gerações de inteletuais de várias proveniências. Num brevíssimo poema, Aventura nos Mares do Sul, Joaquim Namorado exprime como este fascínio, transformado em nostalgia, se reconverte num forte apelo ausente por estes espaços: “Eu nunca fui lá..."

O confronto permanente entre a terra e a água, a luta constante entre o ser humano e o mar inscreve marcas contraditórias e faz com que a "fome existencial do ilhéu ultrapasse os limites da estreita fronteira contornada pelo mar para se projetar na procura do mais além. O visível não lhe chega, ele tem necessidade do imaginário. Este, por sua vez, não sacia a sua sede. Ele se sente atraído pelo real existente que transborda a medida da ilba" (Veiga, 1998: 9). A insularidade é, como refere, "essa camisa de força que tolbe os gestos e nos fecunda o peito, que nos faz sentir o sabor agridoce da evasão, da partida e do regresso" e constitui importante fonte inspiradora que os criadores cabo-verdianos foram plasmando na literatura, na poesia e na música, referências incontornáveis da identidade deste povo. "Livre de ir onde quiser/ e no entanto prisioneiro", era assim a Pátria, lugar de exílio, de Daniel Filipe, para quem a paisagem não passava dum "Mar em azul inesperado/ Ilba, começo e fim do mundo", cuja condição de ilhéu implicava observar "a paisagem interior: cumes, rios, valados, desenharem-se no espaço, / contornados a dor, / (...) onde invento sozinho outra geografia." Em Estórias contadas, Germano de Almeida faz-nos uma lapidar síntese deste universo insular: "é assim o cabo-verdiano: orgulhoso do centro da terra onde vive, sofre e labuta contra a permanente estiagem, os olbos no estrangeiro, o coração nas ilhas." 
A áurea de mistério que as ilhas encerram apela a vários tipos de viagem: entre os seus naturais, a superação dos limitados horizontes suscita a contemplação, a evasão introspetiva, enquanto a superação da geografia madrasta se faz através da ausência física, do êxodo para a terra longe; para quem lhes é exterior, as ilhas exercem a atração pelo desconhecido, são lugares que representam um exótico imaginado que desencadeia o desejo de conhecer, de visitar. Por todos estes indeléveis motivos, as ilhas transformaram-se em locais de destino ou de passagem de distintas rotas, onde circulam, anualmente, milhões de turistas, das mais variadas origens, em demanda de míticos paraísos perdidos onde sempre se deseja regressar.

\subsection{Ultraperiferia e turismo insular: Cabo Verde, espaço aberto à coope-} ração e à integração regional

A posição mais meridional de Cabo Verde na Macaronésia, espaço onde se incluem as outras Ilhas Atlânticas situadas além-Gibraltar (Açores, Madeira e Canárias), e a sua articulação com os continentes que lhe são relativamente equidistantes (Europa, África e América), ditaram o percurso histórico, económico, social, cultural e político do arquipélago. Ponto de passagem para as Américas e plataforma de entrada no Atlântico Sul, Cabo Verde viu mudar, ao longo do tempo, o papel e as funções estratégicas que foi chamado a desempenhar no contexto global: foi entreposto negreiro, até ao início do século XIX, permanecendo marcas profundas e incontornáveis desse tempo de escravatura; foi base de recrutamento de pescadores e marinheiros, para a pesca da baleia e para a marinha mercante, atividades e canais que estiveram na génese duma diáspora que acabou por radicar importantes comunidades cabo-verdianas em países tão improváveis como os Estados Unidos e a Holanda; foi local estratégico no apoio às comunicações intercontinentais transatlânticas, tanto portuárias (Porto Grande de S. Vicente) e aeroportuárias (Sal), como noutras formas de comunicar, transportar e difundir informação que se sucederam ao longo do século XX (do telégrafo aos call-centers). 
Superar as dificuldades, as incertezas do meio e a angústia desse estado de alma, intangível e inexplicável, chamado insularidade, ajudou a desenvolver entre os cabo-verdianos uma cultura da ausência, da partida para terra longe, levou-os a aceitar resignadamente a emigração forçada ou a viagem potencialmente redentora para escapar a uma vida de privações. Assim se formou um povo e um território abertos, física e mentalmente, aonde aportam pessoas, bens e conhecimentos de várias partes do Mundo e donde, ininterruptamente, tem partido um fluxo de homens obrigados a percorrer os caminhos da emigração. Mais recentemente, quando o país atinge um patamar económico e social mais elevado, tornou-se mais apelativo e passou a ser, com idêntica naturalidade, também um espaço de acolhimento: para cabo-verdianos que retornam; para alguns imigrantes, sobretudo africanos, provenientes de países mais próximos; mas, fundamentalmente, para um número crescente de turistas, sobretudo europeus.

Ultrapassar as limitações e condicionantes geográficas, económicas e sociais obrigou a tirar partido da principal oportunidade e do recurso mais abundante: a geografia e o mar. "O poeta e ensaísta David Hopffer Almada, profundo conbecedor da legislação bumana e biológica do Arquipélago, demonstra-nos que a crioulidade é o resultado das travessias no deserto, no meio de terras calcinadas, de rochas ressequidas e do défice de comunicação - por falta de uma gramática da fraternidade durante longos séculos -, mas também é o resultado de uma luta tenaz que acabou por recriar uma nova gramática no chão das ilhas e uma nova faina cultural e identitária que tem muito de comum com a "azagua" agrícola do Arquipélago." Ao longo dos tempos Cabo Verde fez a ligação a vários destinos, tendo no mar a sua enorme e verdadeira auto-estrada, como é amplamente reconhecido: "O «ciclo do mar" forjou, pois, a nossa insularidade, mas também levou-nos a descobrir que se o mundo começa em nossa "casa", o universo não se restringe apenas às nossas ilhas. Daí a nossa grande vocação ao diálogo e à cooperação, numa perspetiva de reconversão constante, de reconstrução inacabável e de afirmação assumida de uma crioulidade com personalidade recriada diante do "outro" com quem dialoga, com quem coopera." (Veiga, 1998: 9). 
Perante tal pano de fundo e correndo o risco de privilegiar uma visão eurocêntrica, já que com a Europa Cabo Verde estabeleceu um acordo privilegiado de cooperação, parece importante abordar três aspetos importantes para enquadrar e melhor interpretar as atuais dinâmicas do turismo no arquipélago: comparar Cabo Verde com outros espaços insulares, sobretudo os que constituem as ultraperiferias da Europa do Sul; posicionar Cabo Verde no contexto dos principais destinos turísticos insulares mundiais; e explorar a integração regional e geoestratégica do arquipélago proporcionada pelas ligações aos canais afetivos criados pela diáspora.

O enquadramento de Cabo Verde e das Ilhas da Macaronésia no contexto da Europa do Sul acentua a importância da geografia e do quadro económico, social e político vigentes, onde este pequeno arquipélago representa um caso singular, dado estarmos perante um país que passou dum sistema colonial, em vigor até à independência (1975), para um regime de partido único e, depois, multipartidário, após a abertura ocorrida em 1990. Estes fatores e a comparação com as ilhas onde, por afinidades históricas e geográficas, naturalmente se integra (Macaronésia), evidenciam todas as caraterísticas que enquadram Cabo Verde no conceito de ultraperiferia ${ }^{2}$

2 O conceito foi desenvolvido no contexto das políticas regionais europeias, visando descriminar positivamente, sete regiões consideradas ultraperiféricas: "as Ilhas Canárias, os Açores e a Madeira, no oceano Atlântico, que desde o século XVI foram para Espanha e Portugal escalas intermediárias nas rotas marítimas transoceânicas; Martinica, Guadalupe e a Guiana, no Caribe, mais tarde colonizadas por França, do mesmo modo que a Ilha de Reunião, no Oceano Índico. A maioria destes territórios tinha um valor estratégico de localização para as suas metrópoles europeias que perderam com a descolonização do resto da África e América durante os séculos XIX e XX. Os territórios europeus ultraperiféricos constituem, em si mesmos, uma singularidade territorial por motivos evidentes de índole geográfica e histórica.

Devido à sua singularidade, compartilharam condicionantes de desenvolvimento similares e hoje deparam-se com desafios económicos parecidos. (...) As condicionantes territoriais das regiões europeias ultraperiféricas podem ser sintetizadas da seguinte forma:

- Estão muito afastadas geograficamente do continente europeu;

- Encontram-se isoladas, tanto por se tratar de ilhas oceânicas como por se limitarem com territórios pouco povoados, basicamente florestais e com níveis de desenvolvimento relativamente baixos, assim como com carência de comunicações diretas com o seu entorno geográfico e dificuldade de relações comerciais por pertencerem a áreas económicas diferentes;

- São territórios de pequena superfície, com recursos naturais escassos;

- Têm uma elevada fragmentação, no caso dos arquipélagos, fator que provoca uma dupla insularidade nas ilhas menores." 
tal como compara as caraterísticas de outros arquipélagos também fortes concorrentes quanto ao exercício desta atividade económica. Os espaços insulares mediterrânicos não devem ser excluídos nesta apreciação por se tratar igualmente de fortes concorrentes devido à proximidade e à qualidade da oferta perante o grande centro emissor de turismo que é a Europa.

Observando o posicionamento de Cabo Verde entre os principais destinos do turismo insular mundial (quadro 1) conclui-se que o arquipélago começa a ganhar visibilidade e adquire alguma expressão quantitativa, pelos 250.000 estrangeiros que visitaram o país em 2006, ficando ao nível de destinos como as Seychelles, as Ilhas Virgens britânicas ou as Ilhas Caimão, para dar apenas alguns exemplos. Para o Norte desenvolvido as ilhas do Sul sempre exerceram forte apelo pela viagem, com imaginários que alimentam o turismo, atividade bastante volátil, sujeita a múltiplas variáveis, das modas às ditaduras do mercado e dos seus operadores, bem como das conjunturas económicas às crises sanitárias e securitárias, onde pesam, sobretudo, os conflitos e as guerras. Em tempo de crise como os que se vivem atualmente, conjugando o fato de os destinos insulares mais longínquos se revelarem de difícil acesso e a instabilidade no Magreb desviar fluxos significativos de turistas, Cabo Verde pode afirmar-se como

\begin{tabular}{|c|c|c|c|c|}
\hline & Localização & Capital & Superfície $\left(\mathrm{km}^{2}\right)$ & População (habitantes) \\
\hline Açores & Oceano Atlântico & Ponta Delgada & 2333 & 237900 \\
\hline Madeira & Oceano Atlântico & Funchal & 795 & 244800 \\
\hline Canárias & Oceano Atlântico & Las Palmas & 7447 & 1715700 \\
\hline Guiana & América do Sul & Cayenne & 84000 & 161100 \\
\hline Martinica & Mar das Caraíbas & Fort-de-France & 1080 & 383300 \\
\hline Guadalupe & Mar das Caraíbas & Basse-Terre & 1710 & 425700 \\
\hline Saint-Barthélémy & Mar das Caraíbas & Gustavia & 25 & 8300 \\
\hline Saint-Martin & Mar das Caraíbas & Marigot & 53 & 35000 \\
\hline Reunião & Oceano Índico & Saint-Denis & 2510 & 715900 \\
\hline Saint-Martin & Mar das Caraíbas & Marigot & 53 & 35000 \\
\hline Cabo Verde & Oceano Atlântico & & 4033 & 491600 \\
\hline
\end{tabular}

Fonte: As regiões ultraperiféricas da União Europeia: Indicadores para caraterizar a ultraperificidade (http://www.mcrit.com/rup/documentos/RUP_MEMORIA_FINAL_POR_def.pdf) 
um destino turístico insular, complementar ou alternativo para o mercado europeu, relativamente a destinos já afirmados, seja o das ilhas mediterrânicas ou os mais longínquos (Cuba, Caraíbas, Maurícias, Seychelles, por exemplo), mantendo a oportunidade de continuar a aumentar o potencial de crescimento de que tem dado provas.

QuAdro 1 - Cabo Verde no contexto do turismo insular: principais regiões e territórios insulares de destino

\begin{tabular}{|c|c|c|c|c|c|c|}
\hline \multirow[b]{2}{*}{ Ilhas } & \multirow{2}{*}{$\begin{array}{c}\text { Superfície } \\
\mathrm{Km}^{2}\end{array}$} & \multirow{2}{*}{$\begin{array}{c}\text { População } \\
2003\end{array}$} & \multirow{2}{*}{$\begin{array}{c}\mathrm{N}^{\mathrm{o}} \text { de } \\
\text { visitantes } \\
\text { estrangeiros } \\
(2004)\end{array}$} & \multicolumn{2}{|c|}{ Densidade } & \multirow[b]{2}{*}{$\begin{array}{c}\text { Visitantes/ } \\
\text { Habitantes } \\
(\%)\end{array}$} \\
\hline & & & & $\begin{array}{l}\mathrm{Hab} / \\
\mathrm{Km}^{2}\end{array}$ & $\begin{array}{l}\text { Visitantes/ } \\
\quad \mathbf{K m}^{\mathbf{2}}\end{array}$ & \\
\hline Cabo Verde & 4.033 & 434.812 & 241.752 & 107,8 & 59,9 & 55.6 \\
\hline África & 7.529 & 3.241 .000 & 1.866 .000 & 430,5 & 247,8 & 57,6 \\
\hline Comores & 1.862 & 749.000 & 14.000 & 402,3 & 7,5 & 1,9 \\
\hline Maldivas & 297 & 309.000 & 564.000 & $1.040,4$ & $1.899,0$ & 182,5 \\
\hline Maurícias & 2.040 & 1.210 .000 & 702.000 & 593,1 & 344,1 & 58,0 \\
\hline Mayotte & 373 & 160.000 & 32.000 & 429,0 & 85,8 & 20,0 \\
\hline Réunion & 2.512 & 730.000 & 432.000 & 290,6 & 172,0 & 59,2 \\
\hline Seychelles & 445 & 83.000 & 122.000 & 186,5 & 274,2 & 147,0 \\
\hline Caraíbas & 26.940 & 3.677 .600 & 6.711 .000 & 136,5 & 249,1 & 182,5 \\
\hline $\begin{array}{l}\text { Anguilla } \\
\text { (colónia britânica) }\end{array}$ & 91 & 8.800 & 47.000 & 96,7 & 516,5 & 534,1 \\
\hline Antígua e Barbuda & 442 & 79.000 & 224.000 & 178,7 & 506,8 & 283,5 \\
\hline Antilhas Holandesas & 800 & 219.000 & 726.000 & 273,8 & 907,5 & 331,5 \\
\hline Bahamas & 13.939 & 312.000 & 1.510 .000 & 22,4 & 108,3 & 484,0 \\
\hline Barbados & 431 & 269.000 & 531.000 & 624,1 & $1.232,0$ & 197,4 \\
\hline \multicolumn{7}{|l|}{ Ilhas Virgens } \\
\hline $\begin{array}{l}\text { Ilhas Virgens Americanas } \\
\text { (território dos EUA) }\end{array}$ & 352 & 124.000 & 538.000 & 352,3 & $1.528,4$ & 433,9 \\
\hline $\begin{array}{l}\text { Ilhas Virgens Britânicas } \\
\text { (colónia britânica) }\end{array}$ & 153 & 12.600 & 278.000 & 82,4 & $1.817,0$ & 2206,3 \\
\hline $\begin{array}{l}\text { Ilhas Caymans } \\
\text { (colónia britânica) }\end{array}$ & 264 & 38.000 & 294.000 & 143,9 & $1.113,6$ & 773,7 \\
\hline Dominica & 751 & 74.000 & 73.000 & 98,5 & 97,2 & 98,6 \\
\hline Granada & 345 & 94.000 & 142.000 & 272,5 & 411,6 & 151,1 \\
\hline
\end{tabular}




\begin{tabular}{|c|c|c|c|c|c|c|}
\hline \multirow[b]{2}{*}{ Ilhas } & \multirow{2}{*}{$\begin{array}{c}\text { Superfície } \\
\mathbf{K m}^{2}\end{array}$} & \multirow{2}{*}{$\begin{array}{c}\text { População } \\
2003\end{array}$} & \multirow{2}{*}{\begin{tabular}{|c|}
$\mathbf{N}^{\circ}$ de \\
visitantes \\
estrangeiros \\
$(2004)$
\end{tabular}} & \multicolumn{2}{|c|}{ Densidade } & \multirow[b]{2}{*}{$\begin{array}{c}\text { Visitantes/ } \\
\text { Habitantes } \\
\text { (\%) }\end{array}$} \\
\hline & & & & $\begin{array}{l}\mathrm{Hab} / \\
\mathrm{Km}^{2}\end{array}$ & $\begin{array}{c}\text { Visitantes/ } \\
\mathbf{K m}^{2}\end{array}$ & \\
\hline $\begin{array}{l}\text { Guadalupe (departamento } \\
\text { ultramarino da França) }\end{array}$ & 1.779 & 428.000 & 439.000 & 240,6 & 246,8 & 102,6 \\
\hline $\begin{array}{l}\text { Martinica (departamento } \\
\text { ultramarino da França) }\end{array}$ & 1.102 & 383.000 & 453.000 & 347,5 & 411,1 & 118,3 \\
\hline $\begin{array}{l}\text { Montserrat } \\
\text { (colónia britânica) }\end{array}$ & 102 & 12.000 & 8.000 & 117,6 & 78,4 & 66,7 \\
\hline Santa Lúcia & 617 & 151.000 & 277.000 & 244,7 & 448,9 & 183,4 \\
\hline Saint Kitts e Nevis & 269 & 38.000 & 91.000 & 141,3 & 338,3 & 239,5 \\
\hline São Martinho & 86 & & 428.000 & 0,0 & $4.976,7$ & \\
\hline São Vicente e Granadinas & 389 & 115.000 & 79.000 & 295,6 & 203,1 & 68,7 \\
\hline Trinidad e Tobago & 4.528 & 1.306 .000 & 409.000 & 288,4 & 90,3 & 31,3 \\
\hline $\begin{array}{l}\text { Turks e Caicos } \\
\text { (colónia britânica) }\end{array}$ & 500 & 14.200 & 164.000 & 28,4 & 328,0 & 1154,9 \\
\hline Pacífico & 59.687 & 1.615 .000 & 2.514 .000 & 27,1 & 42,1 & 155,7 \\
\hline Cook (N.Z) & 236 & 20.000 & 78.000 & 84,7 & 330,5 & 390,0 \\
\hline $\begin{array}{l}\text { Estados Federais da } \\
\text { Micronésia }\end{array}$ & 701 & 129.000 & 18.000 & 184,0 & 25,7 & 14,0 \\
\hline Fidji & 18.000 & 832.000 & 431.000 & 46,2 & 23,9 & 51,8 \\
\hline Guam (USA) & 541 & & 910.000 & 0,0 & $1.682,1$ & \\
\hline Kiribati & 849 & 85.000 & 5.000 & 100,1 & 5,9 & 5,9 \\
\hline Marianas do Norte (USA) & 471 & & 452.000 & 0,0 & 959,7 & \\
\hline Marshall & 181 & 53.000 & 7.000 & 292,8 & 38,7 & 13,2 \\
\hline Niue (N.Z) & 258 & & 3.000 & 0,0 & 11,6 & \\
\hline Nova Caledónia (Fr) & 18.576 & & 102.000 & 0,0 & 5,5 & \\
\hline Palau & 459 & 20.000 & 68.000 & 43,6 & 148,1 & 340,0 \\
\hline Polinésia Francesa & 3.521 & & 213.000 & 0,0 & 60,5 & \\
\hline Samoa Ocidental & 2.831 & 159.000 & 92.000 & 56,2 & 32,5 & 57,9 \\
\hline Samoa (USA) & 199 & & 44.000 & 0,0 & 221,1 & \\
\hline Tonga & 650 & 100.000 & 40.000 & 153,8 & 61,5 & 40,0 \\
\hline Tuvalu & 24 & 10.000 & 1.000 & 416,7 & 41,7 & 10,0 \\
\hline Vanuatu & 12.190 & 207.000 & 50.000 & 17,0 & 4,1 & 24,2 \\
\hline
\end{tabular}

Fonte: adaptado de TAGLIONI, François (2003)

http://hal.archives-ouvertes.fr/docs/00/04/86/63/PDF/Setion_1.pdf 
A condição ultraperiférica de Cabo Verde relativamente ao mercado europeu não impede que o país explore uma integração territorial e turística assente no enquadramento geopolítico, aproveitando igualmente as ligações afetivas estabelecidas e consolidadas por uma geografia sentimental construída pela diáspora.

A integração regional e internacional do universo cabo-verdiano já se pode observar nos voos dos TACV (figura 1): Cabo Verde, a origem, parece marcar a margem sul da Europa, enquanto os lugares de destinos são cidades onde então se implantaram sucessivas vagas de emigrantes. Os Estados Unidos, para onde começaram a sair nos barcos baleeiros, os países africanos mais próximos (Guiné e Senegal) ou que faziam parte do império colonial português (S. Tomé e Angola), os europeus (Portugal, Holanda, Espanha e França) e, mais recentemente, o Brasil, não deixam de representar, também, a natural área de influência e de mercado para onde se pode expandir o turismo de Cabo Verde.

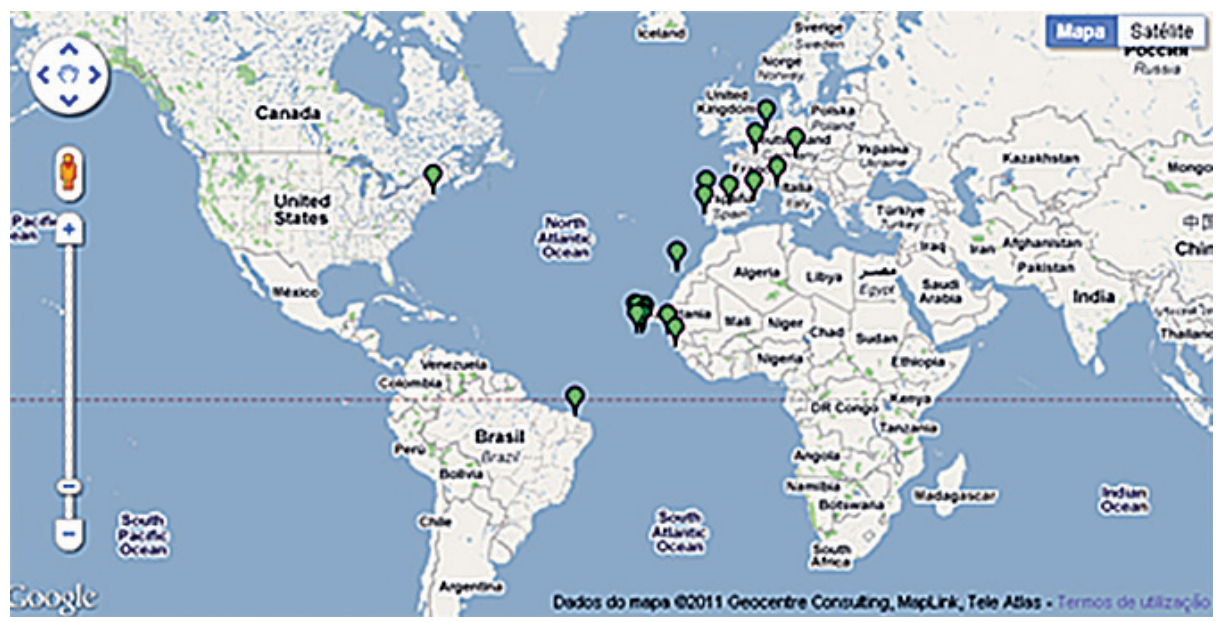

FIgURA 1 - Aeroportos para onde voam os TACV Cabo Verde Airlines Fonte: (http://pt.dohop.com/travel-guide//companhias-aereas/TACV\%20Cabo\%20Verde\%20Airlines-0VR/) 


\section{Geografia do turismo de Cabo Verde: valorizar os recursos, afir- mar um destino}

\subsection{Recursos e turismo: identificar, valorizar, promover, gerir}

Se o produto turístico principal das Ilhas de Cabo Verde é o turismo balnear litoral, ou seja o turismo de sol e praia, as condições climáticas, que constituem uma das principais adversidades para as atividades agro-pastoris tradicionais, assumem-se como o principal recurso para o turismo da modernidade.

Segundo Correia (1993) que aplicou às condições climáticas da Ilha de Santiago a classificação de Besancenot, Mounier e Lavenne (1978) e uma outra que constitui uma adaptação do autor com base nos parâmetros Temperatura, Humidade Relativa, Insolação e Velocidade do Vento, as condições climáticas para a prática do turismo balnear litoral são muito boas no setor meridional da Ilha de Santiago, para onde foi feito o estudo. Ainda que este estudo tenha sido baseado numa única estação meteorológica que está situada ligeiramente no interior da Ilha (S. Francisco, a pouco mais de $5 \mathrm{Km}$ da linha de costa e com uma altitude já acima dos $200 \mathrm{~m}$ ) e de ter tido em conta dados de apenas 1 ano (1982), pode ter-se uma ideia efetiva das potencialidades climáticas para o turismo, não só ao nível da Ilha de Santiago, mas também do conjunto do arquipélago. Assim, para além de um elevado número de dias por ano com boas condições para a prática balnear (apenas cerca de $29 \%$ de dias desfavoráveis, segundo a classificação francesa, e um pouco mais $30 \%$, segundo a classificação do Autor), acresce o fato de o melhor período para a prática balnear se situar entre Fevereiro e Julho, ou seja significativamente desajustado da prática balnear litoral nos países europeus e particularmente da sua frente de mar mediterrânea. Os meses de Novembro, Dezembro e Janeiro são meses ainda com boas condições, mas as baixas temperaturas do ar condicionam a atividade balnear. Apenas os meses de Agosto, Setembro e Outubro, correspondentes à "estação das águas" podem ser marcados, nalguns dos seus dias, quer pelo desconforto térmico de uma relação Temperatura/ Humidade excessiva, quer por uma forte nebulosidade, ventos fortes ou, 
mesmo, por precipitações violentas, que comprometem a prática turística em geral e, muito especialmente, a prática balnear litoral.

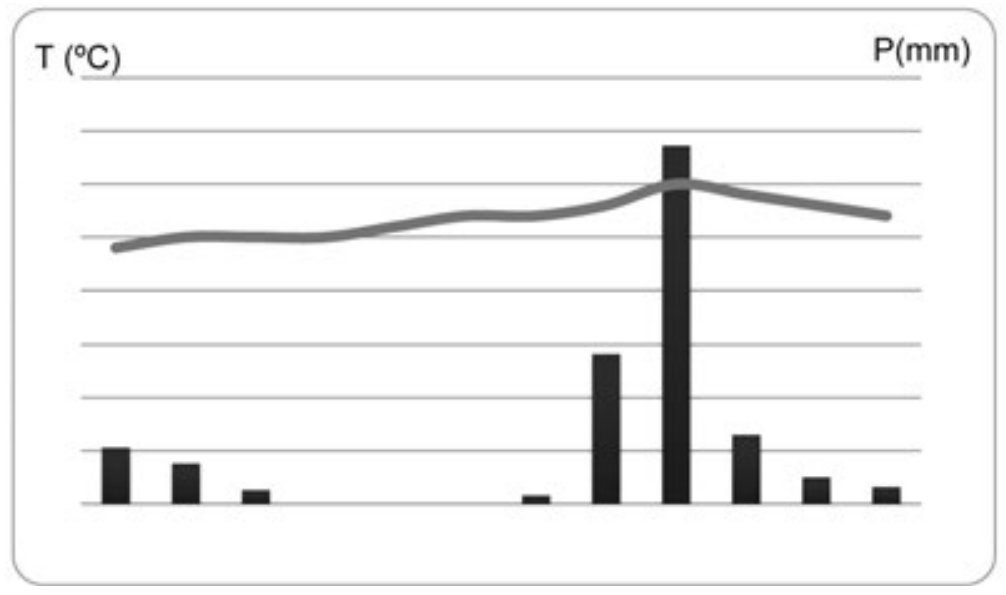

FIgura 2 - Gráfico termopluviométrico da Ilha do Sal

Se os valores da temperatura do ar, a falta de nebulosidade e o vento constante favorecem a prática balnear, a temperatura da água do mar que, em termos médios, varia entre $21^{\circ} \mathrm{C}$ em Fevereiro e $26{ }^{\circ} \mathrm{C}$ em Setembro, torna as praias de Cabo Verde favoráveis a banhos de mar e a atividades desportivas durante todo o ano, sobretudo para os turistas europeus, habituados a temperaturas significativamente inferiores, mesmo na fachada mediterrânica.

No entanto, se as condições climáticas e, particularmente, as condições do ar e da água são extremamente favoráveis, já o mesmo não acontece com a morfologia costeira da maior parte das ilhas. De fato, apenas nas ilhas mais orientais, Sal e Boa Vista, abundam as costas baixas e as praias de areia fina e clara. Nas restantes ilhas, o acidentado do relevo vulcânico proporciona sobretudo costas altas, de arribas, em que se intercalam, aqui e ali, pequenas praias, em regra cascalhentas, extremamente interessantes do ponto de vista cénico, mas com dimensão e qualidade insuficientes para projetar empreendimentos turísticos capazes de atrair visitantes. 
Mas o mar de Cabo Verde é também um importante recurso para atividades desportivas que, acompanhando o turismo, muitas vezes são a sua própria imagem de marca. No caso, falamos especificamente do Surf e de atividades desportivas e de lazer associadas, como o bodyboard, kitesurf e windsurf, bem como do mergulho.

A constância dos alísios durante quase todo o ano favorece a prática do surf, windsurf e kitesurf, particularmente nas ilhas mais voltadas para o turismo internacional, como é o caso das Ilhas do Sal e da Boa Vista. No entanto, também São Vicente, Santo Antão e Santiago proporcionam condições para a prática deste tipo de modalidades que têm vindo a assumir importância crescente, não só localmente, mas também internacionalmente, já que começam a constar dos roteiros especializados e a integrar mesmo competições à escala mundial.

A temperatura das águas, a sua limpidez, a variedade morfológica, plena de grutas e pequenos abrigos subaquáticos, assim como a variedade da flora e sobretudo da fauna marinha, ligada aos processos migratórios anuais, fazem do arquipélago de Cabo Verde um dos locais de mergulho colocados nos itinerários internacionais da modalidade. Apesar de ser uma atividade ainda em desenvolvimento, é possível encontrar nas Ilhas do Sal e da Boa Vista, mas também na Ilha de Santo Antão, empresas especializadas com monitores experientes para acompanhar os turistas nas aventuras exploratórias subaquáticas.

Como já foi referido, outro importante recurso para a prática turística em Cabo Verde é a paisagem insular, marca ou testemunho da interação secular entre o Ser Humano e uma Natureza árida, agreste, vigorosa, mas sempre variada e muito rica. Os socalcos de Santo Antão, os cutelos escalvados de Santiago, as salinas de Pedra Lume (Sal) ou as ralas florestas de Acácia Americana, mais que paisagens naturais das ilhas são lições vivas dessa relação, permitindo verdadeiras aulas práticas de educação ambiental. Por este motivo, particularmente nos Parques Naturais, começam a ser marcados, preparados e divulgados percursos pedestres com diferentes graus de dificuldade, destinados a públicos diversos e que permitem, tanto a leitura e a fruição de paisagens, como o contato direto com a natureza. A rede de Parques Naturais em Cabo Verde permite fruir, apesar de tudo, 
uma variedade enorme de paisagens e de morfologias, contatar com aspetos valiosos de uma biodiversidade muito marcada pelos endemismos das Ilhas e conviver com uma cultura sempre surpreendente e enriquecedora. Assim, para além do turismo balnear e do turismo desportivo que lhe está associado, as ilhas de Cabo Verde têm ótimas condições para o desenvolvimento do turismo ambiental ou de natureza, bem como do turismo ativo.

Numa breve referência, destacam-se o Parque Natural de Monte Gordo, na Ilha de São Nicolau, o Parque Natural de Monte Verde, na Ilha de São Vicente, os parques naturais de Morocos e da Ribeira do Norte, em Santo Antão, o Parque Natural da Serra Malagueta, na Ilha de Santiago, e o Parque Natural da Ilha do Fogo. Esta é a única que, no arquipélago, apresenta vulcanismo ativo, tendo a última erupção ocorrido em 1995 e mantém, por isso, uma morfologia vulcânica direta, que grosseiramente corresponde a um grande aparelho vulcânico a que não falta uma caldeira quase perfeita, a chamada Chã das Caldeiras. A morfologia geral e de pormenor, os vários aspetos geológicos e geomorfológicos ligados a um vulcanismo atual e o modo com o Ser Humano se articula com esta geologia em constante movimento e evolução, fazem com que grande parte da Ilha (acima dos $1500 \mathrm{~m}$ ) tenha um estatuto de proteção ambiental (Parque Natural) que promove e facilita a atividade turística (Vera Alfama et al., 2008).

Aos recursos naturais importa acrescentar os culturais, com destaque para o Património Histórico e para o Património Imaterial. Dentre estes, merece referência especial a Cidade Velha (Ribeira Grande de Santiago), a primeira cidade europeia localizada fora da Europa (1462), primeira capital e, desde 2009, Património da Humanidade, pela sua localização e pelo valor simbólico e patrimonial do seu edificado religioso, militar e civil. Ainda na Ilha de Santiago, é de assinalar o Campo do Chão Bom, no Tarrafal, onde funcionou o campo prisional para adversários do regime ditatorial do Estado Novo e que hoje está parcialmente musealizado.

Entre o património urbano, além dos sobrados de S. Filipe, destaca-se o Plateau - o centro histórico da Capital, onde se concentrava a vida administrativa e se mantêm, embora nem sempre bem conservados, muitos vestígios da arquitetura colonial - e a cidade do Mindelo, cujo núcleo histórico, organizado em função do Porto Grande, embora sem o signifi- 
cado comercial, económico e funcional de outrora, continua a respirar o ambiente de antigos tempos de esplendor.

Como foi dito, a paisagem rural das Ilhas de Cabo Verde traduz o esforço continuado do amanho da terra em condições muito difíceis, tanto em termos climáticos, como em termos orográficos. Daí que nas ilhas mais montanhosas e mais húmidas se assista a verdadeiras obras de engenharia rural no sentido de aproveitar para a produção de milho e feijão, todas as nesgas de terra com um mínimo de qualidade produtiva. Assim, surgiram, por exemplo, as paisagens de socalcos de Santo Antão que, mais do que imagem de marca da Ilha, são exatamente o testemunho desse diálogo difícil, mas frutuoso, da persistência e da inteligência do Ser Humano face ao caráter agreste da Natureza.

Num meio difícil e quase sempre agressivo, a amenidade do povo é fundamental do ponto de vista turístico. Uma sociedade crioula, culta, aberta, generosa e em que se regista uma enorme vontade de contato com o "outro", é marcada por uma morabeza que surpreende quem visita as ilhas. Por outro lado, alguns aspetos desta cultura crioula, nomeadamente no que se refere à música e à literatura, são também importantes ativos para o incentivo à viagem e para o desenvolvimento do turismo internacional.

\subsection{Importância do turismo e (re)organização da atividade: qualificar a oferta, diversificar a procura}

Segundo o Observatório do Turismo de Cabo Verde 3 , "o turismo em Cabo Verde surge com a construção do aeroporto internacional na Ilha do Sal em 1960 e, com ele, arranca uma atividade económica promissora, com a construção de alojamento hoteleiro. Inicialmente muito centrado na Ilha do Sal, rapidamente se espalha a outras ilhas tendo crescido a um ritmo notável: "Entre o ano de 2000 e 2008, o número de turistas em Cabo Verde cresceu a uma média de $11,4 \%$ ao ano, passando de 145.000

3 IPDT - Instituto de Turismo, Observatório do Turismo de Cabo Verde (http://www. observatoriodoturismocv.org/pagina.php?id=41) 
turistas em 2000 para 333.354 em 2008. No que diz respeito às dormidas, deu-se um crescimento médio anual de 14,5\% no mesmo período, passando de 684,7 mil para 1,8 milhões de dormidas em 2008 (idem)”. No entanto cerca de $95 \%$ dos fluxos turísticos centram-se "em apenas quatro ilhas, nomeadamente Sal, (57\%), Santiago (20,1\%), Boavista $(9,9 \%)$ e São Vicente (7,6\%)" (Idem).

Continuando a seguir o Observatório do Turismo, verifica-se que a importância do turismo é muito relevante para a economia do país, já que "é estimado que a entrada de turistas estrangeiros em 2008 tenha gerado 25,3 milhões de contos de receitas para o país, contando-se com um crescimento de $7,8 \%$ face ao ano anterior... ... que o turismo contribua para $19,4 \%$ do $\mathrm{PIB}$, respeitando a $60,8 \%$ do total das receitas do setor dos serviços". Relativamente à entrada de divisas, os dados do Banco de Cabo Verde demonstram um aumento significativo dos gastos dos turistas estrangeiros, cujo crescimento médio anual se situa nos 29\% (idem).

A dimensão recente dos fluxos turísticos para as ilhas de Cabo Verde tem expressão nos indicadores da figura 3. Tanto a procura, traduzida no número de dormidas e de hóspedes, como a oferta, que pode ser vista através do número de estabelecimentos hoteleiros e do número de quartos disponíveis, apontam para a importância turística das Ilhas Rasas ou ilhas orientais, nomeadamente do Sal e da Boavista. Com efeito, estas Ilhas destacam-se, mesmo quando comparamos os números com a Ilha de Santiago (onde se localiza a capital) e com a Ilha de S. Vicente, que inclui a segunda cidade do País, o Mindelo, importante centro administrativo e cultural.

Outro elemento a ter em consideração é a rápida evolução registada na oferta. De fato se pensarmos na evolução recente (de 1999 a 2006), em sete anos quase duplica o número de estabelecimentos hoteleiros, duplica o número de quartos e o emprego ligado ao setor e praticamente triplica a capacidade de alojamento (quadro 2). No que respeita à procura, o número de hóspedes e dormidas quase duplica entre 2001 e 2006, mas este aumento é mais significativo na ilha do Sal e na Ilha da Boavista, que tem vindo a afirmar-se como alternativa à Ilha do Sal, enquanto destino turístico internacional. 

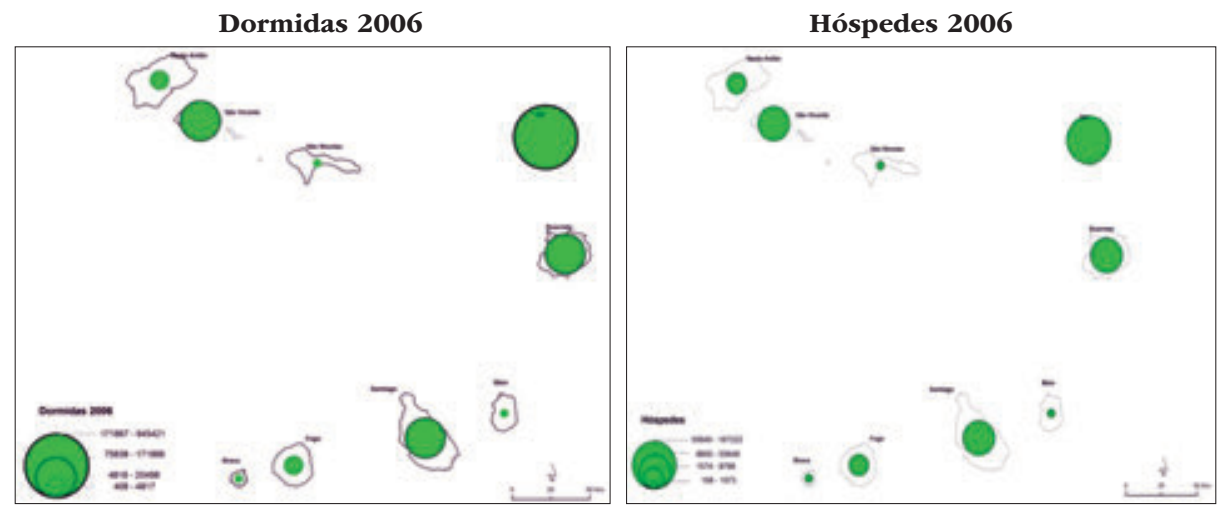

N. ${ }^{\circ}$ de Estabelecimentos 2006
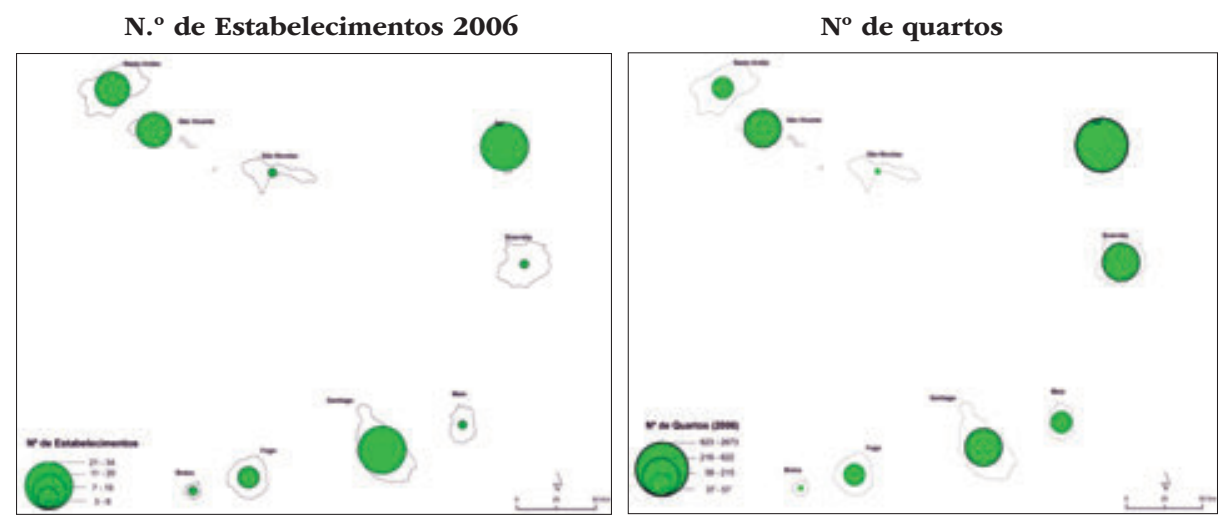

FIgURA 3 - Procura e oferta turística em 2006 por ilha em Cabo Verde

O fenómeno turístico em Cabo Verde tem uma dimensão claramente internacional, ainda que o número de nacionais que viajam e utilizam infra-estruturas turísticas, ainda que nem sempre por razões ligadas ao lazer, atinja os $14 \%$ (quadro 3). De entre os estrangeiros, destacam-se os turistas europeus e, de entre eles, os italianos, portugueses, alemães e franceses que, no seu conjunto, correspondem a cerca de $65 \%$ do número de hóspedes e a cerca de $75 \%$ do número de dormidas. No entanto, este panorama pode alterar-se em breve, uma vez que o destino Cabo Verde passou a ser extremamente apelativo para belgas, holandeses, espanhóis, ingleses e americanos, para referir apenas os países que nos cinco anos que medeiam entre 2001 e 2006, duplicaram o número de turistas em Cabo Verde. 
QuADro 2 - O turismo em Cabo Verde: evolução da capacidade de alojamento, pessoal ao serviço, hóspedes e dormidas por ilha [1999-2006]

\begin{tabular}{|c|c|c|c|c|c|c|c|c|c|c|c|c|}
\hline \multirow[t]{2}{*}{ Ilhas } & \multicolumn{2}{|c|}{$\begin{array}{l}\text { Estabeleci- } \\
\text { mentos }\end{array}$} & \multicolumn{2}{|c|}{ Quartos } & \multicolumn{2}{|c|}{$\begin{array}{c}\text { Capacidade de } \\
\text { Alojamento }\end{array}$} & \multicolumn{2}{|c|}{$\begin{array}{l}\text { Pessoal } \\
\text { Serviço }\end{array}$} & \multicolumn{2}{|c|}{ Hóspedes } & \multicolumn{2}{|c|}{ Dormidas totais } \\
\hline & 1999 & 2006 & 1999 & 2006 & 1999 & 2006 & 1999 & 2006 & 2001 & 2006 & 2001 & 2006 \\
\hline Santo Antão & 6 & 19 & 54 & 215 & 107 & 426 & 26 & 110 & 3.903 & 8.799 & 13.559 & 20.498 \\
\hline Boavista & 6 & 5 & 155 & 614 & 264 & 878 & 110 & 459 & 10.168 & 20.968 & 70.031 & 171.866 \\
\hline Brava & 3 & 5 & 28 & 37 & 50 & 104 & 12 & 15 & 89 & 158 & 5.704 & 409 \\
\hline Fogo & 7 & 10 & 55 & 127 & 120 & 5.854 & 62 & 64 & 4.014 & 4.038 & 11.791 & 7.510 \\
\hline Maio & 2 & 3 & 26 & 68 & 54 & 1.479 & 16 & 21 & 728 & 602 & 7.145 & 2.158 \\
\hline Sal & 14 & 34 & 761 & 2.673 & 1.715 & 136 & 664 & 1.774 & 93.496 & 167.222 & 542.497 & 945.421 \\
\hline Santiago & 22 & 31 & 429 & 622 & 890 & 1.252 & 416 & 507 & 28.196 & 55.648 & 88.570 & 139.501 \\
\hline São Nicolau & 8 & 6 & 55 & 57 & 97 & 253 & 27 & 18 & 1.323 & 1.573 & 5.939 & 4.817 \\
\hline São Vicente & 11 & 20 & 262 & 423 & 577 & 68 & 228 & 322 & 20.178 & 21.574 & 60.688 & 75.838 \\
\hline Cabo Verde & 79 & 133 & 1.825 & 4.836 & 3.874 & 10.450 & 1.561 & 3.290 & 162.095 & 280.582 & 805.924 & 1.368 .018 \\
\hline
\end{tabular}

\subsection{Prospetiva e desenvolvimento do turismo em Cabo Verde: políticas, planos, estratégias}

A escassez de recursos, a dimensão, o caráter arquipelágico e as especificidades históricas do país remeteram os debates sobre as estratégias de desenvolvimento do arquipélago para opções difíceis e complexas, em que o turismo passou a ter, a partir de determinado momento, um lugar de charneira, como se depreende desta observação feita no rescaldo do II Plano Nacional de Desenvolvimento (1986-1990): "O turismo e as atividades ligadas ao transporte aéreo e marítimo têm certamente perspetivas favoráveis de desenvolvimento, em todo o caso, dentro de limites e condicionamentos que não permitem afirmar com segurança que aí se encontra a solução - ou elemento decisivo da mesma - para a estruturação económica de Cabo Verde" (Murteira, 1988: 180). Não é de estranhar, portanto, que sucessivas políticas, planos e estratégias de desenvolvimento tenham dado importância à atividade turística e à valorização dos recursos que, tanto à escala nacional como à escala local, possam vir a sustentar o desenvolvimento de diferentes produtos turísticos. 
QUADRO 3 - Evolução da procura turística em Cabo Verde: hóspedes e dormidas por país de residência habitual (2001 e 2006)

\begin{tabular}{|c|c|c|c|c|c|c|c|c|}
\hline \multirow[b]{2}{*}{ Ilbas } & \multicolumn{3}{|c|}{ Hóspedes } & \multirow[b]{2}{*}{$\begin{array}{c}\text { Var. 01- } \\
06(\%)\end{array}$} & \multicolumn{3}{|c|}{ Dormidas } & \multirow[b]{2}{*}{$\begin{array}{c}\text { Var. 01- } \\
06(\%)\end{array}$} \\
\hline & 2001 & 2006 & $\%$ & & 2001 & 2006 & $\%$ & \\
\hline Cabo Verde & 27.926 & 38.840 & 13,8 & 39,1 & 81.127 & 106.521 & 7,8 & 31,3 \\
\hline Cabo-verdianos & 27.114 & 37.508 & 13,4 & 38,3 & 78.126 & 103.215 & 7,5 & 32,1 \\
\hline Estrangeiros & 812 & 1.332 & 0,5 & 64,0 & 3.001 & 3.306 & 0,2 & 10,2 \\
\hline Estrangeiros & 134.169 & 241.752 & 86,2 & 80,2 & 724.797 & 1.261 .497 & 92,2 & 74,0 \\
\hline Itália & 44.661 & 65.109 & 23,2 & 45,8 & 301.385 & 469.108 & 34,3 & 55,7 \\
\hline Portugal & 36.417 & 59.881 & 21,3 & 64,4 & 163.833 & 284.194 & 20,8 & 73,5 \\
\hline Alemanha & 17.617 & 30.485 & 10,9 & 73,0 & 97.559 & 169.457 & 12,4 & 73,7 \\
\hline França & 11.642 & 25.145 & 9,0 & 116,0 & 39.763 & 100.456 & 7,3 & 152,6 \\
\hline Bélgica + Holanda & 2.694 & 10.675 & 3,8 & 296,3 & 9.004 & 54.785 & 4,0 & 508,5 \\
\hline Espanha & 4.223 & 7.800 & 2,8 & 84,7 & 15.119 & 33.782 & 2,5 & 123,4 \\
\hline Reino Unido & 749 & 5.115 & 1,8 & 582,9 & 2.794 & 21.460 & 1,6 & 668,1 \\
\hline Estados Unidos & 2.382 & 5.949 & 2,1 & 149,7 & 7.716 & 16.474 & 1,2 & 113,5 \\
\hline Suíça & 2.289 & 2.437 & 0,9 & 6,5 & 8.827 & 11.629 & 0,9 & 31,7 \\
\hline África do Sul & 3.392 & 4.659 & 1,7 & 37,4 & 50.785 & 6.196 & 0,5 & $-87,8$ \\
\hline Áustria & 1.216 & 1.326 & 0,5 & 9,0 & 4.862 & 5.288 & 0,4 & 8,8 \\
\hline Outros Países & 6.887 & 23.171 & 8,3 & 236,4 & 23.150 & 88.668 & 6,5 & 283,0 \\
\hline Total & 162.095 & 280.582 & 100,0 & 73,1 & 805.924 & 1.368 .018 & 100,0 & 69,7 \\
\hline
\end{tabular}

Sem nos alongarmos em considerações históricas, importa destacar a Lei de Bases ${ }^{4}$ que declara como "Zonas Turísticas Especiais"5, as "áreas identificadas como possuidoras de especial aptidão para o turismo internacional, pelas potencialidades que apresentem para o desenvolvimento turístico internacional de sol e mar, ou pelo seu valor ecológico”, e estabelece as formas de apropriação de solos das mesmas áreas e as modali-

${ }^{4}$ DECRETO-LEI N. ${ }^{\circ}$ 2/93, de 1 de Fevereiro, Governo, Boletim Oficial da República de Cabo Verde de 1 de Fevereiro de 1993, onde se apresentam conceitos como: c) "Recursos turísticos", os bens que pelas suas caraterísticas naturais, culturais ou recreativas tenham capacidade de motivar visita e fruição turísticas"

5 Posteriormente regulamentadas: Boavista (1) D-R n. ${ }^{\circ}$ 7/94-B.O. n. ${ }^{\circ}$ 20, de 23/05/94; Maio (2) D-R n. ${ }^{\circ}$ 18/97-B.O n. ${ }^{\circ}$ 50, de 30/12/97; Sal (3) D-R n. ${ }^{\circ} 12 / 05-B . O . n .{ }^{\circ} 11$, de 13/03/06; Santiago (4) D-R n. ${ }^{\circ}$ 9/98-B.O. n. ${ }^{\circ} 48$, de 31/12/98; São Vicente (5) D-R n. ${ }^{\circ}$ 8/98B.O. n. ${ }^{\circ} 48$, de $31 / 12 / 98$. 
dades da sua cedência aos promotores turísticos. As opções tomadas na sequência da adoção desta legislação, plasmadas em diferentes estudos e planos, culminaram, no passado mais recente, com a elaboração de alguns documentos fundamentais ${ }^{6}$, suportados nas orientações do Programa do Governo para a Legislatura 2006/2012 que apontava: "O Governo continuará a considerar o turismo como o motor principal da economia" 7 .

Neste contexto, o Plano Estratégico para o Desenvolvimento do Turismo em Cabo Verde (2010/2013), "enquanto instrumento sobretudo de comunicação, de orientação e de coordenação dos diversos agentes públicos e privados no desenvolvimento do turismo sustentado" tem como objetivos principais: i) Identificar as potencialidades turísticas do país no contexto das oportunidades decorrentes da conjuntura atual e esperada do setor a nível mundial; ii) Identificar as áreas de melhoria e os pontos de bloqueio ao crescimento sustentável do turismo no país; iii) Definir e comunicar uma visão clara sobre que turismo se pretende para Cabo Verde, em linha com a estratégia de desenvolvimento do país elaborada pelo Governo; iv) Estabelecer políticas e orientações estratégicas que norteiam programas de ação visando alcançar objetivos previamente definidos no setor do turismo, bem como identificar os recursos necessários para a sua materialização; v) Estabelecer mecanismos eficazes de monitorização e avaliação dos resultados da sua implementação".

Abarcando áreas transversais (acessos, infra-estrutura geral, infra-estrutura turística, estrutura institucional, sustentabilidade e monitorização), os 17 Programas Estratégicos (PE’s) definidos pelo Plano Estratégico de

${ }^{6}$ PNUD (2004a), Rapport National sur le Développement Humain Cap Vert-2004, Praia. Master Plan do Turismo: http://www.ic.cv/InvetExterno.html http://www.unotur.com/encontro/PromoCV_MARCOS_NOVA.pps\#257,1,Diapositivo Plano Estratégico para o Desenvolvimento do Turismo em Cabo Verde 2010/2013, MINISTÉRIO DE ECONOMIA, CRESCIMENTO E COMPETITIVIDADE - DIREÇÃO GERAL DO TURISMO (tenbo pdf)

http://www.observatoriodoturismocv.org/multimedia/pedtcv.pdf http://www.observatoriodoturismocv.org/pagina.php?id=41 http://portoncv.gov.cv/dhub/porton.por_global.open_file?p_doc_id=762

Plano de Marketing para o turismo de Cabo Verde - apresentação 23 de Julho de 2010. http://www.observatoriodoturismocv.org/pagina.php?id=89

7 Fonte: http://www.governo.cv/ 
Desenvolvimento do Turismo ${ }^{8}$, ao visarem "uma intervenção coordenada e multisetorial abarcando toda a cadeia de valor do turismo”, pretendem concorrer para: “i) aumentar a competitividade de Cabo Verde como destino turístico; ii) garantir a sustentabilidade da atividade turística a curto, médio e longo prazo; e iii) maximizar a interiorização e democratização dos benefícios do turismo”.

A definição de um plano de marketing para o turismo de Cabo Verde (2010/2011), na ótica da promoção do destino Cabo Verde, apresentado a 23 de Julho de 2010, levou em consideração "o atual cenário do destino (destino emergente, com tendência de elevado crescimento em termos de fluxos turísticos; de elevado potencial turístico, pela riqueza dos recursos naturais e humanos; com recursos financeiros limitados; e com necessidades de desenvolvimento infra-estrutural e organizacional numa perspetiva social e turística urgente)", apontando como objetivo específico "definir o posicionamento de Cabo Verde que instrua o desenvolvimento da marca turística 'umbrella' do país - país único, diferenciado dos demais destinos identificados como concorrentes diretos”, partindo dos seguintes pressupostos: definir o posicionamento de cada ilha numa lógica de produto (de acordo com a atual oferta); definir uma estratégia de segmentação do turismo de Cabo Verde (de acordo com os atuais principais mercados emissores e tipologia de turistas atuais e potenciais); definir as ações

\footnotetext{
8 Programas Estratégicos (PE's) previstos no Plano Estratégico de Desenvolvimento do Turismo (17):

Dimensão "ACESSOS": 1. Ligar o Mundo às Ilhas; 2. Ligar as Ilhas Entre Si; 3. Viajar nas Ilhas;

Dimensão "INFRA-ESTRUTURA GERAL": 4. Mais Saúde Também Para Quem nos Visita; 5. Mais Segurança Também Para Quem nos Visita; 6. Água, Energia e Saneamento para o Desenvolvimento Turístico; 7. Melhor Suporte de Comunicações e Produtos Financeiros para o Desenvolvimento Turístico.

Dimensão "INFRA-ESTRUTURA TURÍSTICA": 8. Receber Nossos Visitantes com Conforto e Qualidade; 9. Promover o Destino Cabo Verde com Eficiência; 10.Política Fiscal para um Turismo Sustentável.

Dimensão "ESTRUTURA INSTITUCIONAL": 11. Melhor Gestão do Turismo Nacional; 12. Melhor Legislação para o Desenvolvimento do Turismo.

Dimensão "SUSTENTABILIDADE: 13. Mais Ambiente para Mais Turismo; 14. Mais Cultura para Mais Turismo; 15. Para um Turismo com Rosto Social.

Dimensão "MONITORIZAÇÃO: 16.Avaliar para Melhorar; 17. Conhecer o Turista para Melhor o Servir.
} 
de promoção do destino; identificar oportunidade de desenvolvimento turístico sustentável" 9.

O posicionamento individual e a imagem de cada ilha foram definidos a partir duma análise que valorizou "as caraterísticas únicas (recursos naturais), as infra-estruturas (recursos construídos), as acessibilidades (entre ilhas), e os públicos alvo potenciais, cujas condições de oferta não sejam uma limitação à motivação da visita, pelo contrário, constituam vantagens competitivas na atração de turistas com determinado perfil”, permitindo agrupar as dez (10) ilhas do arquipélago de modo a orientá-las para "públicos distintos (nichos), com motivações diferentes". O quadro onde se sistematizam as conclusões apresentadas no âmbito do referido Plano de Marketing mostra que a promoção da oferta turística tem por base recursos e um imaginário de Cabo Verde que aponta para os seguintes produtos: Produtos âncora (Oferta Genérica): clima/sol, cultura crioula, segurança, proximidade; Produtos complementares (Oferta Específica): desportos, história, natureza, gastronomia.

Reconhece o estudo que cada ilha de Cabo Verde, "individualmente, não tem representatividade para ser promovida ... com exceção do Sal, da Boavista, de Santiago e de S. Vicente, que apresentam um nível de desenvolvimento em termos de recursos infra-estruturais que lhes confere alguma autonomia ao nível do desenvolvimento turístico.” A imagem genérica de Cabo Verde assenta em slogans ${ }^{10}$ e numa mensagem básica como argumentos para vender turisticamente Cabo Verde (quadro 4): "10 ilhas, 10 ingredientes para umas férias de sonho ..."11.

\footnotetext{
9 Plano de Marketing para o turismo de Cabo Verde: http://www.observatoriodoturismocv.org/pagina. php?id=89.

10 "One country, ten destinations ..." (para todos os produtos); "The Alternative Cape Verde ..." (para os novos produtos); "Apaixone-se" (para as ilhas do sol); "Envolva-se" (para as ilhas da essência); "Surpreenda-se" (para as ilhas dos sentidos).

11 SAFE (easy and friendly people); SAVOURY (exquisite and natural gastronomy); SECURE (no natural disasters, no diseases, no vaccines); SENSUAL (music and dance all over); SIMPLE (very close to Europe - 3, 5 hours); SMOOTH (total relaxation); SOBER (authentic and cultural); SPECIAL (young and unique atmosphere); SPORTIVE (ideal for sea sports); SUNNY (365 days per year).
} 
QUADRO 4 - O turismo em Cabo Verde: visão prospetiva e estratégica do posicionamento e segmentação, dos produtos e distribuição segundo o Plano de Marketing

\begin{tabular}{|c|c|c|c|c|}
\hline \multicolumn{2}{|c|}{ A IMAGEM DAS ILHAS } & $\begin{array}{c}\text { Ilhas do Sol } \\
\text { [Sal / Boavista / Maio] }\end{array}$ & $\begin{array}{c}\text { Ilhas do } \\
\text { Glamour } \\
\text { [Santiago / São } \\
\text { Vicente] }\end{array}$ & $\begin{array}{l}\text { Ilhas dos Sentidos } \\
\text { [Santo Antão / Santa Luzia } \\
\text { / São Nicolau / Fogo / } \\
\text { Brava] }\end{array}$ \\
\hline \multicolumn{2}{|c|}{ PRODUTO ÂNCORA } & Sol e praia & $\begin{array}{l}\text { Negócios/ } \\
\text { Eventos e Lazer }\end{array}$ & Natureza insólita \\
\hline \multicolumn{2}{|c|}{$\begin{array}{c}\text { PRODUTOS } \\
\text { COMPLEMENTARES }\end{array}$} & $\begin{array}{l}\text { Desportos náuticos e } \\
\text { aquáticos }\end{array}$ & $\begin{array}{l}\text { Cultura (História, } \\
\text { Música, Dança e } \\
\text { Gastronomia) }\end{array}$ & $\begin{array}{l}\text { Cultura (História, Música, } \\
\text { Dança e Gastronomia), } \\
\text { Natureza e Desportos } \\
\text { (trekking, BTT, caminhadas, } \\
\text { observação de aves e } \\
\text { espécies marinhas) }\end{array}$ \\
\hline \multirow[b]{2}{*}{$\begin{array}{l}\text { MERCADOS } \\
\text { EMISSORES }\end{array}$} & $\begin{array}{l}\text { Atuais com } \\
\text { expressão }\end{array}$ & $\begin{array}{l}\text { Reino Unido, Alemanha, } \\
\text { Itália, Portugal, Cabo } \\
\text { Verde (mercado interno } \\
\text { e diáspora) }\end{array}$ & $\begin{array}{l}\text { Portugal, França, } \\
\text { Cabo Verde } \\
\text { (mercado interno } \\
\text { e diáspora) }\end{array}$ & $\begin{array}{l}\text { Cabo Verde (mercado } \\
\text { interno e diáspora) e } \\
\text { França }\end{array}$ \\
\hline & $\begin{array}{c}\text { Com } \\
\text { potencial }\end{array}$ & $\begin{array}{l}\text { Espanha, França, } \\
\text { Escandinávia, Holanda, } \\
\text { Rússia, Polónia, } \\
\text { República Checa, EUA }\end{array}$ & $\begin{array}{l}\text { Suíça, Alemanha, } \\
\text { Espanha, } \\
\text { Itália, Bélgica, } \\
\text { Luxemburgo, } \\
\text { Holanda, Reino } \\
\text { Unido, Brasil } \\
\end{array}$ & $\begin{array}{l}\text { Holanda, Áustria, } \\
\text { Escandinávia, Alemanha, } \\
\text { Reino Unido, EUA e Canadá }\end{array}$ \\
\hline \multicolumn{2}{|c|}{$\begin{array}{c}\text { SEGMENTOS/ } \\
\text { /NICHOS DE MERCADO }\end{array}$} & $\begin{array}{l}\text { 1) Famílias (casais } \\
\text { jovens com filhos } \\
\text { menores) } \\
\text { 2) Casais jovens sem } \\
\text { filhos } \\
\text { 3) Casais + } 55 \text { anos que } \\
\text { viajam sem filhos } \\
\text { 4) Cabo verdeanos da } \\
\text { diáspora } \\
\text { 5) Grupos ou } \\
\text { indivíduos que } \\
\text { procuram desportos } \\
\text { náuticos e/ou aquáticos }\end{array}$ & $\begin{array}{l}\text { 1) Viajantes } \\
\text { individuais } \\
\text { 2) Grupos } \\
\text { 3) Casais }+30 \\
\text { anos que viajam } \\
\text { sem filhos } \\
\text { 4) Cabo } \\
\text { verdeanos da } \\
\text { diáspora }\end{array}$ & $\begin{array}{l}\text { 1) Viajantes individuais e/ } \\
\text { ou Grupos (exploradores, } \\
\text { historiadores, cientistas, } \\
\text { amantes da natureza e de } \\
\text { desportos associados) } \\
\text { 2) Casais }+30 \text { anos } \\
\text { que viajam sem filhos } \\
\text { (segmento dos } 30 \text { aos } 60 \\
\text { anos) }\end{array}$ \\
\hline
\end{tabular}

Fonte: Observatório do Turismo (simplificado)

http://www.observatoriodoturismocv.org/multimedia/PLANO\%20DE\%20MARKETING\%20CABO\%2O

VERDE\%20-\%202010-2011\%20-\%2023_07_2010.pdf

Num contexto natural tão sensível, as relações entre o turismo, o ambiente e a biodiversidade assumem preocupações acrescidas, testemunhadas pelas múltiplas referências feitas em diversos trabalhos e planos ${ }^{12}$ :

12 MINISTÉRIO DO AMBIENTE, AGRICULTURA E PESCAS GABINETE DE ESTUDOS E PLANEAMENTO. Segundo Plano de Ação Nacional para o Ambiente DOCUMENTO SINTESE 
"O turismo sustentável é uma atividade promotora do bem-estar social, da preservação ambiental, do crescimento económico e do desenvolvimento harmonioso e equilibrado de um país. O desenvolvimento do turismo em Cabo Verde deve ser encarado na base da seguinte visão: Um país com um turismo sustentável desenvolvido em todo o país e em cada ilha em função das potencialidades reais existentes e garantindo um impato sócio-económico durável.”

É reconhecido que, tanto a qualidade do ambiente depende do desenvolvimento equilibrado do turismo, como a degradação do ambiente tem impatos negativos diretos sobre esta atividade. Assim, por outro lado, o turismo tem impatos positivos e negativos sobre o ambiente (entre os positivos estão a contribuição para a proteção dos recursos naturais e para melhoria da gestão dos mesmos e, entre os negativos, estão o aumento do lixo, os riscos de poluição da água e dos solos e, sobretudo, o aumento da pressão sobre os recursos hídricos e energéticos). Por outro lado, com uma procura turística de nível internacional e muito assente em atividades desportivas ligadas ao mar, a boa qualidade ambiental é condição absolutamente necessária para o seu desenvolvimento. A monitorização dos indicadores ambientais revela-se importante para acompanhar a evolução dum "fenómeno que é muito importante nas ilhas sahelianas onde o ambiente é frágil e o desenvolvimento do turismo, ainda que moderado, pode ter impatos proporcionalmente elevados" (idem).

O rápido desenvolvimento do turismo em todas as ilhas de Cabo Verde, além duma reflexão importante sobre as questões do ambiente em geral, deve estender estas preocupações às questões da biodiversidade e da

(2004-2014). VOLUME I: TEXTO PRINCIPAL Praia, Março de 2004. http://www.governo.cv/ documents/PANAII-sintese-final.pdf

Livro Branco sobre o Estado do Ambiente em Cabo Verde - 2004 (Capítulo sobre Turismo) http://www.sia.cv/documentos/Livrobranco.pdf (Cap. turismo pp. 120 e segs.). MINISTÉRIO DO AMBIENTE E AGRICULTURA. DIREÇÃO-GERAL DO AMBIENTE. TERCEIRO RELATÓRIO NACIONAL SOBRE O ESTADO DA BIODIVERSIDADE EM CABO VERDE. Cidade da Praia, Setembro de 2006 [Equipa Técnica: Manuel Leão Silva de Carvalho; Sónia Indira Araújo. Financiamento: Global Environment Facility. Edição: Direção-Geral do Ambiente.

AUTO - AVALIAÇÃO DAS CAPACIDADES NACIONAIS PARA A GESTAO GLOBAL AMBIENTAL (NCSA - GEM). RELATÓRIO DE TRANVERSALIDADE E SINERGIA ENTRE AS TRÊS CONVENÇÕES DE RIO (CCD, CBD, CCC). Documento Final, PRAIA, Abril de 2007. Elaborado pelos Consultores: Charles Yvon Rocha; Sónia Elsy Merino; Arlinda Duarte Neves. pp: 13. 
gestão de espaços incluídos nos parques e nas reservas naturais, bem como às questões do desenvolvimento urbano sustentável.

\section{Turismo e desenvolvimento em Cabo Verde: competitividade, sus- tentabilidade, coesão}

Os efeitos sobre a economia e a criação de emprego colocam o turismo entre as atividades estruturantes das sociedades e territórios insulares. No entanto, os impates registados a diferentes escalas (nacional, regional - de cada uma das ilhas - e local), obrigam a colocar sob observação a evolução global do setor e os comportamentos e práticas dos seus principais atores. No caso concreto de Cabo Verde, estas razões impõem que haja uma atenção particular à recomendação sobre o turismo sustentável em Pequenos Estados Insulares (PEI) e outras ilhas ${ }^{13}$, que entende o turismo "como um elemento mais do desenvolvimento sustentável global de cada ilha", onde se "devem definir desafios e oportunidades de desenvolvimento turístico a médio prazo e os cenários possíveis a longo prazo" e que advoga

13 A CONFERENCIA INTERNACIONAL SOBRE EL TURISMO SOSTENIBLE EN PEQUEÑOS ESTADOS INSULARES (PEI) Y OTRAS ISLAS, realizada em Lanzarote (Espanha), 25-28 de outubro de 1998, apresentou as seguintes recomendações que os organismos internacionais e em particular o PNUMA e a OMT deviam adotar à escala internacional:

- encorajar os PEI a ratificar, quando ainda o não tenham feito, os convénios internacionais e regionais pertinentes, e ajudá-los a cumprir os compromissos de conformidade com esses convénios (Convenções dos Mares Regionais, Convenção sobre a Diversidade Biológica, Convenção para a Proteção do Património Mundial, Protocolo de Montreal, etc.);

- prestar assistência para o estabelecimiento e a aplicação prática de:

- transferência de tecnologia e de conhecimentos técnicos para todos os planos de desenvolvimento sustentável no setor turístico;

- sistemas voluntários como códigos deontológicos e etiquetas ecológicas;

- indicadores e observatórios;

- intercâmbios de experiências à escala internacional sobre turismo sustentável nos PEI;

- melhor difusão de projetos piloto e de boas práticas;

- organizar campanhas de sensibilização e atividades de capacitação para o turismo sustentável ou participar nelas. 
que o "turismo sustentável nos PEI implicará uma mudança de mentalidade de todos os participantes no desenvolvimento e gestão do turismo".

Esta abordagem será rematada por três linhas fundamentais de reflexão:

- competitividade: dinâmica setorial e reestruturação económica;

- sustentabilidade: equilíbrio turismo-ambiente;

- coesão: assimetrias e (re)organização sócio-territoriais (superação das clivagens rural/urbano; litoral/interior; vivência interna/diáspora).

\subsection{Competitividade: dinâmica setorial e reestruturação económica}

O quadro 5 mostra o peso das diferentes atividades económicas no Produto Interno Bruto de Cabo Verde. Para além do destaque óbvio do setor terciário (68\% em 2006), destaca-se o peso das atividades ligadas ao setor do turismo (hóteis e restaurantes) que representa, por si só, 6\% do PIB e que foi o que maior crescimento teve de 2000 a 2006 (cerca de $185 \%)$. Se ao peso direto de hotéis e restaurantes juntarmos o peso de outras atividades que de algum modo estão também relacionadas, direta ou indiretamente, com a atividade turística (transportes aéreos, comunicações, no setor terciário, bem como construção e abastecimento de eletricidade e água) torna-se evidente o peso económico do turismo no conjunto do país.

QUADRO 5 - Produto Interno Bruto em 2006 e evolução recente por atividade económica

(1) Milhares de contos. PM (Preços do mercado; Preços constantes de 1980)

\begin{tabular}{|l|r|r|r|r|r|r|r|r|}
\hline & \multicolumn{2}{|c|}{ Preços (1) } & \multicolumn{3}{|c|}{} \\
\hline & constantes & Correntes & & \% (*) & & & \multicolumn{2}{c|}{ Variação (*) } \\
\hline & $\mathbf{2 0 0 6}$ & $\mathbf{2 0 0 6}$ & $\mathbf{1 9 8 0}$ & $\mathbf{1 9 9 0}$ & $\mathbf{2 0 0 0}$ & $\mathbf{2 0 0 6}$ & $\begin{array}{c}\mathbf{1 9 8 0}- \\
-\mathbf{2 0 0 0}\end{array}$ & $\begin{array}{c}\mathbf{2 0 0 0}- \\
-\mathbf{0 6}\end{array}$ \\
\hline SETOR PRIMARIO & $\mathbf{1 7 2 7 , 9}$ & $\mathbf{1 1 1 5 4 , 6}$ & 19,2 & 14,5 & 9,7 & 6,6 & 62,4 & $-3,1$ \\
\hline agricultura, pecuária, silvicultura & $1.317,1$ & 6894,8 & 13,7 & 12,4 & 8,1 & 5,0 & 88,7 & $-11,1$ \\
\hline pesca & 172,8 & 1224,9 & 4,8 & 1,2 & 0,9 & 0,7 & $-40,0$ & 4,4 \\
\hline indústrias extrativas & 237,9 & 3034,9 & 0,6 & 0,8 & 0,7 & 0,9 & 272,4 & 75,1 \\
\hline & & & & & & & & \\
\hline SETOR SECUNDARIO & $\mathbf{4 3 5 8 , 2}$ & $\mathbf{1 2 5 8 2 , 7}$ & 16,3 & 19,5 & 16,2 & 16,6 & 218,4 & 46,7 \\
\hline congelaçâo, conservas de peixe & 25,6 & 128,3 & 1,2 & 0,2 & 0,1 & 0,1 & $-61,5$ & $-4,8$ \\
\hline
\end{tabular}




\begin{tabular}{|c|c|c|c|c|c|c|c|c|}
\hline & \multicolumn{2}{|c|}{ Preços (1) } & \multirow[b]{3}{*}{1980} & \multirow{3}{*}{$\begin{array}{c}\%(*) \\
1990\end{array}$} & \multirow[b]{3}{*}{2000} & \multirow[b]{3}{*}{2006} & & \\
\hline & constantes & Correntes & & & & & \multicolumn{2}{|c|}{ Variação (*) } \\
\hline & 2006 & 2006 & & & & & $\begin{array}{l}1980- \\
-2000\end{array}$ & $\begin{array}{c}2000- \\
-06\end{array}$ \\
\hline outras indústrias alimentares & 171,9 & 1071,1 & 1,0 & 2,3 & 1,9 & 0,7 & 491,9 & $-51,6$ \\
\hline tabaco & 11,3 & 84,2 & 0,1 & 0,1 & 0,1 & 0,0 & 132,1 & $-37,4$ \\
\hline mecânica e reparaçâo naval & 8,1 & 90,8 & 0,2 & 0,6 & 0,1 & 0,0 & 15,0 & $-42,9$ \\
\hline carpintaria & 250,5 & 782,6 & 1,0 & 1,2 & 1,0 & 1,0 & 204,6 & 38,9 \\
\hline $\begin{array}{l}\text { outras indústrias transformado- } \\
\text { ras }\end{array}$ & 236,8 & 1020,6 & 0,9 & 0,8 & 1,4 & 0,9 & 388,6 & $-5,8$ \\
\hline eletricidade e água & 705,7 & 337,7 & $-0,3$ & 0,5 & 1,7 & 2,7 & $-1690,9$ & 124,7 \\
\hline construçâo & $2.948,3$ & 9067,4 & 12,1 & 13,9 & 9,9 & 11,2 & 161,6 & 62,9 \\
\hline SETOR TERCIARIO & 17755,7 & 65988,8 & 58,2 & 60,6 & 65,8 & 67,6 & 263,0 & 47,1 \\
\hline comércio & $5.021,4$ & 17421,7 & 29,0 & 23,3 & 18,5 & 19,1 & 104,3 & 48,2 \\
\hline botéis e restaurantes & $1.487,7$ & 3072,3 & 0,8 & 1,4 & 2,9 & 5,7 & 1041,8 & 183,2 \\
\hline transportes rodoviários & $1.083,8$ & 6766,7 & 2,8 & 2,8 & 3,6 & 4,1 & 313,0 & 66,0 \\
\hline transportes marítimos & 271,8 & 525,5 & 1,8 & 3,3 & 3,5 & 1,0 & 530,3 & $-57,9$ \\
\hline transportes aéreos & 684,1 & 3764,9 & 0,8 & 0,7 & 3,3 & 2,6 & 1217,1 & 13,4 \\
\hline serviços aos transportes & 574,9 & 3682,2 & 2,9 & 2,8 & 2,7 & 2,2 & 195,7 & 16,3 \\
\hline comunicações & $2.583,5$ & 5815,3 & 0,7 & 2,6 & 8,1 & 9,8 & 3702,8 & 74,2 \\
\hline bancos e seguros & 736,2 & 4178,5 & 2,6 & 1,5 & 2,7 & 2,8 & 227,2 & 48,8 \\
\hline habitaçôes e locais & $1.858,5$ & 5694,8 & 6,4 & 7,7 & 6,4 & 7,1 & 220,9 & 58,6 \\
\hline serviços governamentais & $2.958,7$ & 12521,1 & 9,6 & 13,1 & 12,6 & 11,3 & 323,6 & 27,6 \\
\hline outros serviços & 495,2 & 2546,0 & 0,8 & 1,3 & 1,6 & 1,9 & 546,5 & 66,8 \\
\hline $\begin{array}{l}\text { serviços bancários } \\
\text { não imputados }\end{array}$ & $-657,8$ & $-3322,6$ & $-1,9$ & $-1,5$ & $-2,1$ & $-2,5$ & 251,2 & 71,8 \\
\hline direitos e taxas/importações & $3.066,9$ & 10980,7 & 8,2 & 6,9 & 10,4 & 11,7 & 305,8 & 61,5 \\
\hline TOTAL & 26250,9 & 97384,3 & 100,0 & 100,0 & 100,0 & 100,0 & 221,0 & 43,1 \\
\hline
\end{tabular}

Fonte: INE - Cabo Verde - Contas Nacionais

\subsection{Sustentabilidade: o equilíbrio turismo-ambiente}

Apesar de todas as contradições que o conceito de desenvolvimento sustentável começa a suscitar nos investigadores, nos técnicos e nos cidadãos que, cerca de 25 anos passados sobre o seu nascimento, continuam a não conseguir encontrar, na prática e, sobretudo, a nível global ou nacional, bons exercícios de promoção de desenvolvimento com uma dimensão intergeracional ao nível da preservação dos recursos, da conservação do ambiente, do equilíbrio económico, da justiça social e da 
governança política, o paradigma da sustentabilidade continua a nortear e a enquadrar do ponto de vista teórico, políticas, planos e práticas de desenvolvimento, particularmente a nível das atividades turísticas.

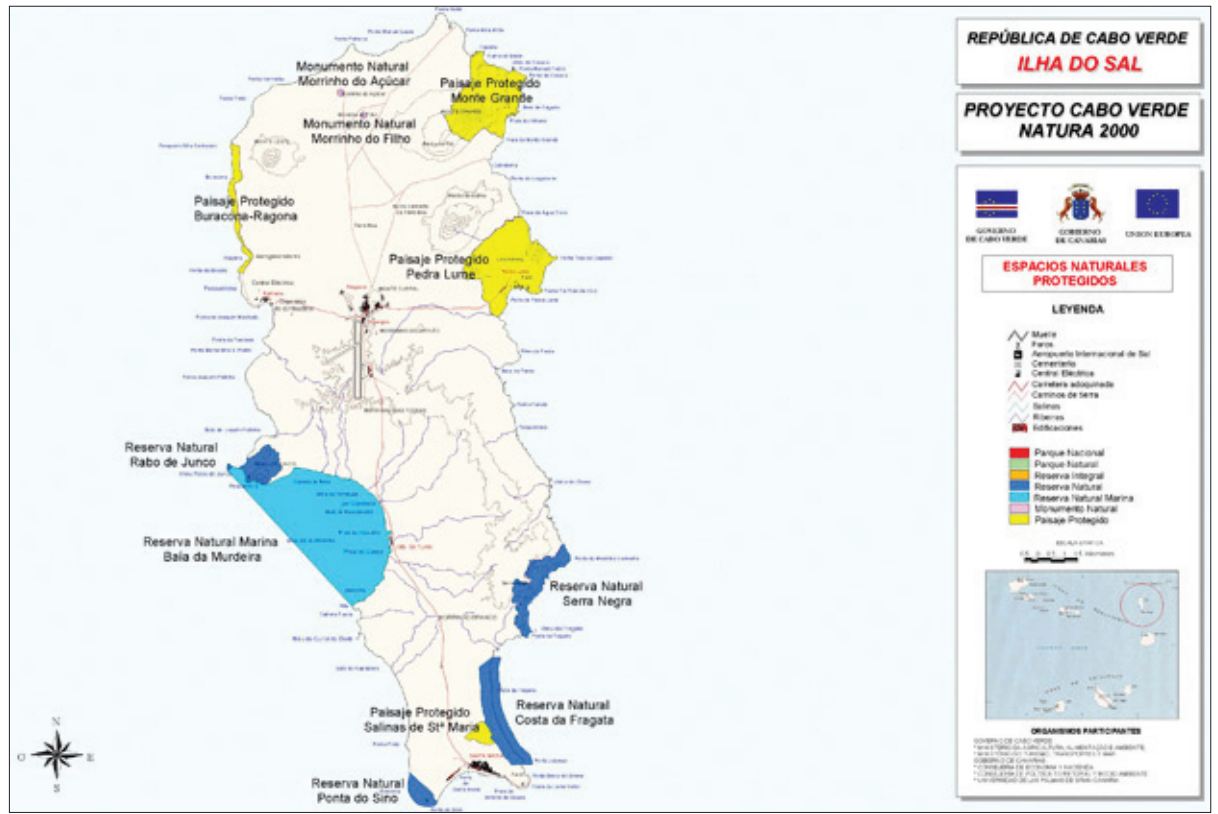

Figura 4 - Zonamento ambiental da Ilha do Sal no âmbito da rede Natura 2000 fonte: http://www.sia.cv/index.php?option=com_content\&view=article\&id=88\&Itemid=108\&lang=pt

Pelo menos a nível local, o desenvolvimento sustentável e a sustentabilidade do turismo são conceitos, se não associados, pelo menos que têm de ser compatíveis, dada a necessidade de uma boa qualidade ambiental para um desenvolvimento turístico de qualidade.

No caso específico de Cabo Verde são muitas e de diferentes tipos as fragilidades e mesmo as vulnerabilidades ambientais, a começar nas condições climáticas, no explosivo crescimento urbano através de construção informal, na má qualidade das infra-estruturas de saneamento básico, em práticas agrícolas e pecuárias desadequadas às condições das ilhas e até na utilização das praias como locais de extração de inertes (LOPEs, 2011). 
No entanto, a procura crescente de algumas ilhas (Sal, Boavista, Santiago, S. Vicente, Fogo) pelo turismo internacional tem levado, ou pelo menos acelerado, a concretização de alguns projetos de salvaguarda ambiental que em muito contribuirão para um desenvolvimento sustentado das Ilhas.

Apresenta-se, a título de exemplo, um projeto para a definição de áreas protegidas no âmbito da Rede Natura 2000, curiosamente financiado pela União Europeia e preparado por entidades das Ilhas Canárias, parceiros e ao mesmo tempo concorrentes no turismo macaronésio. Neste trabalho (figura 4) são inventariados os principais territórios com valor ambiental e paisagístico, no que pode ser considerado também um levantamento de recursos para o turismo Natureza, complemento natural do turismo de Sol e Mar, o principal produto turístico da Ilha.

\subsection{Coesão: assimetrias e (re)organização sócio-territorial}

Finalmente, o turismo pode representar um papel importante na difícil tarefa de construção da coesão territorial do país. De fato, o caráter arquipelágico impõe dinâmicas económicas distintas, diferencia oportunidades de desenvolvimento e acentua assimetrias naturais. A dinâmica demográfica registada nos últimos anos (figura 5) espelha esta diferenciação.

Assim se compreende a maior densidade populacional registada em 2010 nas Ilhas de Santiago (serviços administrativos), São Vicente (serviços administrativos e culturais) e Sal (turismo). Assim se compreende, também, que as Ilhas predominantemente rurais (Santo Antão, São Nicolau, Fogo e Brava) tenham perdido população nos últimos 10 anos, enquanto as restantes e, particularmente, as ilhas com vocação turística (Sal, Boavista e Maio), assim como as ilhas onde se concentram as funções comerciais e administrativas (Santiago e São Vicente) a tenham vindo a ganhar. Ao criar oportunidades de emprego em ilhas menos desenvolvidas, o turismo tem vindo assim, de algum modo, a contribuir para o equilíbrio demográfico do arquipélago.

A fragmentação do território, pelo seu caráter insular, é um dos principais problemas em termos de coesão. As distâncias físicas, os preços 
dos transportes, as dificuldades no transporte de alguns tipos de bens são obstáculos ao desenvolvimento das ilhas mais periféricas, num contexto de circulação de pessoas e bens, sobretudo através de transporte aéreo.

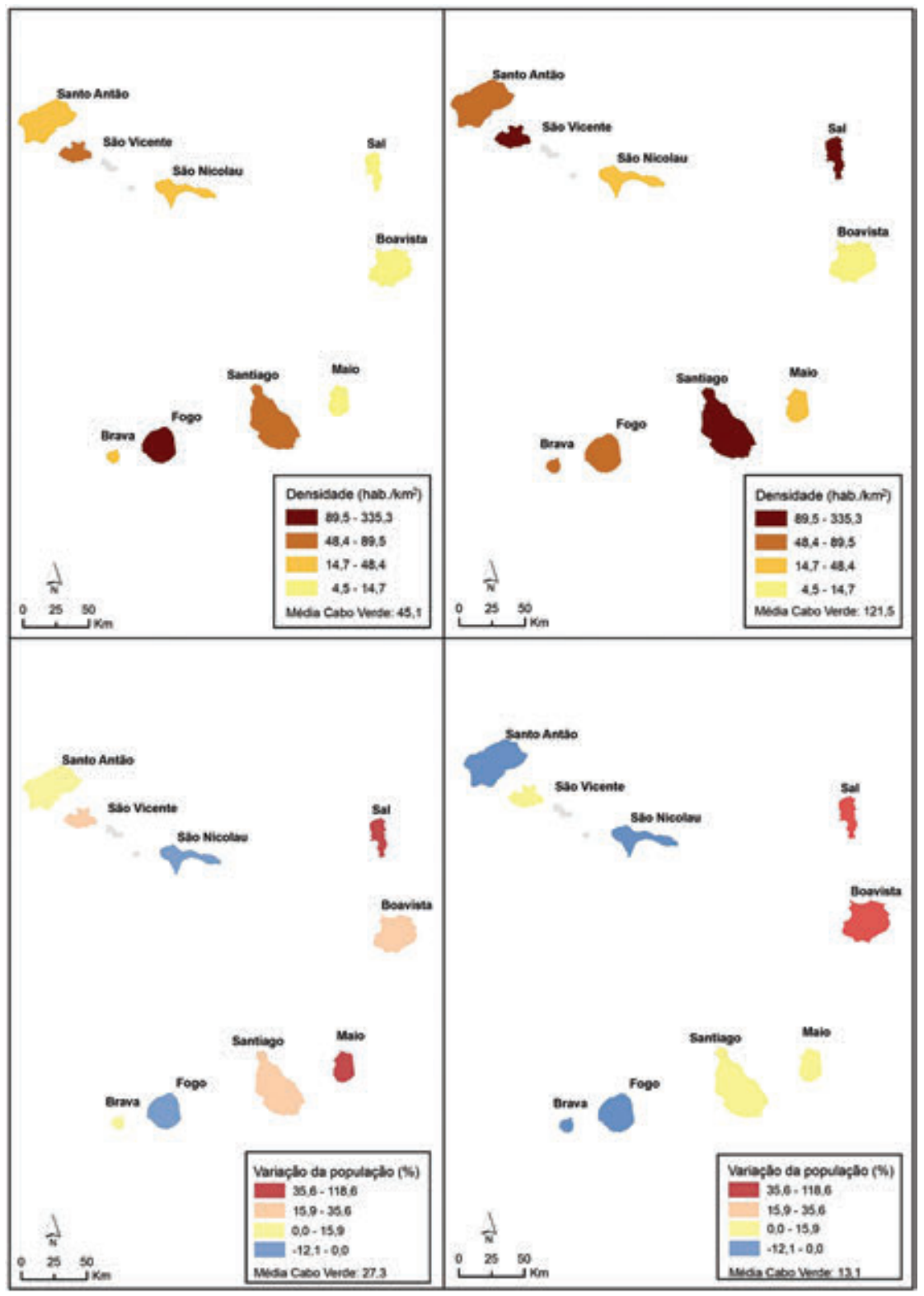

FIgurA 5 - Densidade da população (1940 e 2010) e variação da intercensitária da população (1990/2000 e 2000/2010) nas ilhas de Cabo Verde 
O desenvolvimento do turismo internacional veio modificar o padrão de relacionamento das Ilhas de Cabo Verde com o Mundo e, se há cinco anos atrás, o único aeroporto internacional (Europa, África e América) que servia o país era o da Ilha do Sal, atualmente os voos internacionais chegam e partem também de Santiago, da Boavista e de S. Vicente.

Por outro lado, a nível interno, a rede de transportes aéreos permite o acesso quase imediato a todas as ilhas, com exceção das ilhas mais ocidentais (Santo Antão e Brava; figura 6). Num modelo de desenvolvimento turístico que procura, como referimos, ainda que para diferentes públicos e jogando com recursos distintos, atingir todas as ilhas, a viabilidade da atual rede de transportes aéreos é um fator fundamental na coesão territorial.

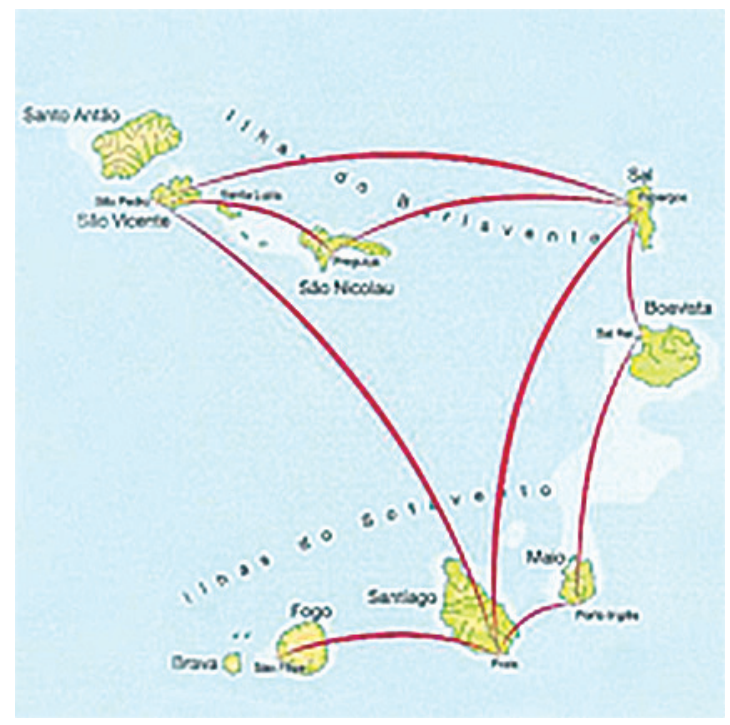

Figura 6 - As linhas domésticas do TACV e a organização do espaço do arquipélago de Cabo Verde

\section{Conclusão}

A atividade turística em Cabo Verde assenta num conjunto de fatores naturais, históricos, sociais e locativos que se combinam de modo feliz para permitir uma atratabilidade notável a nível do mercado internacional. 
Se as condições climáticas ("sol em 365 dias por ano" poderia ser o slogan) são a base, a história da construção de um povo crioulo e de uma nação arquipelágicos, com aspetos culturais ímpares na música e na literatura, e a posição de charneira entre a Europa, a África e a América são os fatores que favorecem o desenvolvimento de uma atividade em crescimento lento mas sustentável e que é fundamental para o crescimento económico do arquipélago.

Para além dos recursos naturais, os recursos humanos são fundamentais no desenvolvimento do turismo. Para além dos recursos histórico-culturais já mencionados, Cabo Verde é um dos países africanos com mais elevada taxa de literacia e com melhor formação dos seus quadros médios e superiores. Esta formação, adquirida inicialmente na Europa e no Brasil, começa a ser a ministrada nas várias escolas superiores do país e constitui um elemento fundamental na construção de uma oferta turística de qualidade.

As crises económicas recentes levaram tanto a um retraimento dos investimentos externos no país, como a uma diminuição da procura turística a nível internacional, tendo afetado, de algum modo, o crescimento económico do país com base nas atividades turísticas. No entanto, existe uma enorme potencialidade para crescimento, potencialidade que terá de ser equacionada em termos de versatilidade, de diferenciação de produtos e de sustentabilidade ambiental, quer dizer, em termos de criação de uma actividade económica moderna, geradora de riqueza, desenvolvimento e equidade social a nível local e nacional.

Ao mesmo tempo que, enquanto actividade económica, o turismo é capaz de promover desenvolvimento e equidade a nível interno e a ajudar a afirmar o país no quadro internacional, ele será também o motor para políticas e práticas de conservação e gestão a nível ambiental, ou seja, permitirá efectivamente contribuir para um desenvolvimento sustentável: conciliação entre as práticas de um turismo com futuro ou de um turismo economicamente sustentável com um ambiente limpo e saudável e uma sociedade equilibrada, rica, diversa e culturalmente genuína. 


\section{Referências bibliográficas}

Alfama, V., Gomes A. \& Brilha, J. 2008, Guia geoturístico da Ilha do Fogo, Coimbra: Departameno de Ciências da Terra da FCTUC, 61 p.

AlmeIdA, G. 2003, Cabo Verde, uma viagem pela história das ilhas, Lisboa: Caminho.

Amaral, I. 1964, Santiago de Cabo Verde. A terra e os homens, Memórias da Junta de Investigação do Ultramar, n. ${ }^{\circ} 48$.

Auto-Avaliação das capacidades nacionais para a gestão global ambiental (NCSA-GEM). Relatório de transversalidade e sinergia entre as três convenções de rio (CCD, CBD, CCC). Documento Final, PRAIA, Abril de 2007. Elaborado pelos Consultores: Charles Yvon Rocha; Sónia Elsy Merino; Arlinda Duarte Neves. 13 p.

CARreira, A. 1982, Estudos de economia Cabo-verdiana, Lisboa: INCM.

CARreira, A. 1983, Cabo Verde. Formação e extinção de uma sociedade escravocrata (1460-1878), Praia: Instituto Cabo-verdiano do Livro.

Carreira, A. 1983, Migrações nas ilhas de Cabo Verde, Praia: Instituto Cabo-verdiano do Livro.

Correia, E. 1993, Condições climáticas para o turismo balnear em Santiago (Cabo Verde). Aplicação de duas classificações, Garcia da Horta, Revista do Instituto de Investigação Científica Tropical, Lisboa, 14 (1 e 2), pp. 41-56.

Correia, R. 2011, Erosão hídrica e agricultura na Ilha de Santiago. Um olhar geográfico na perspectiva da teoria dos riscos. In CunHA, Lúcio e JACINTO, Rui - Interioridades/Insularidades - Despovoamento/Desertificação: paisagens, riscos naturais e educação ambiental em Portugal e Cabo Verde. Guarda: CEI, pp. 159-175.

Cunha, Lúcio, JACinTo, Rui (coord.; 2011), Interioridades/Insularidades - Despovoamento/Desertificação: paisagens, riscos naturais e educação ambiental em Portugal e Cabo Verde. Guarda: CEI.

LOPES, B., 1947, Chiquinho.

LOPES, E. 2011, Mulheres e Ambiente - A problemática da "apanha" de inertes na Ilba de Santiago (Cabo Verde). Diss. Mestrado em Geografia Física, Ambiente e Ordenamento do Território, Coimbra.

Lopes, M. 1956, Chuva Braba.

Lopes, M.1959, O Galo Que Cantou Na Baía.

LOPES, M. 1959, Os Flagelados do Vento Leste. 
Ministério do Ambiente e Agricultura. Direção-Geral do Ambiente. Terceiro Relatório Nacional sobre o Estado da Biodiversidade em Cabo Verde. Cidade da Praia, Setembro de 2006 [Equipa Técnica: Manuel Leão Silva de Carvalho; Sónia Indira Araújo. Financiamento: Global Environment Facility . Edição: Direção-Geral do Ambiente

Monteiro, S. \& CunHa, Lúcio 2011, Cheias rápidas em Cabo Verde. Um breve apontamento acerca das tempestades de Setembro de 2009 na Ilha de S. Nicolau. In CUnHA, Lúcio e JACINTO, Rui - Interioridades/Insularidades - Despovoamento/ Desertificação: paisagens, riscos naturais e educação ambiental em Portugal e Cabo Verde. Guarda: CEI, pp. 177-189.

Monteiro, S. \& Mendes, J. 2011, Riscos Naturais e percepção da vulnerabilidade em Cabo Verde. In Cunha, Lúcio e JACinTo, Rui - Interioridades/Insularidades - Despovoamento/ Desertificação: paisagens, riscos naturais e educação ambiental em Portugal e Cabo Verde. CEI, Guarda, pp. 135-157.

Murteira, M. 1988, Os estados de língua portuguesa na economia mundial. Lisboa: Presença.

NAscimento, J. 2011, Cidade e desenvolvimento urbano em Cabo Verde. In Cunha, Lúcio e JACINTO, Rui - Interioridades/Insularidades - Despovoamento/Desertificação: paisagens, riscos naturais e educação ambiental em Portugal e Cabo Verde. Guarda: CEI, pp. 235-256.

Ribeiro, M. 1961, A Ilha de Santiago. Contribuição para o estudo da sua fenomenologia socio-económica, Coimbra: FLUC (Tese de licenciatura).

Ribeiro, O. 1960, A Ilha do Fogo e as suas erupções. Memórias da Junta de Investigação do Ultramar, n. ${ }^{\circ} 1$.

Riga, A., Vieira, E. \& Borges, M. 2011, Taiti. Diagnóstico geotécnico e ambiental. In CunHA, Lúcio e JACINTO, Rui - Interioridades/Insularidades - Despovoamento/ Desertificação: paisagens, riscos naturais e educação ambiental em Portugal e Cabo Verde. Guarda: CEI, pp. 207-222.

SEMEdo, J. 2011, Cabo Verde: insularidade, desertificação e gestão dos recursos naturais. In CUNHA, Lúcio e JACINTO, Rui - Interioridades/Insularidades - Despovoamento/ Desertificação: paisagens, riscos naturais e educação ambiental em Portugal e Cabo Verde. Guarda: CEI, pp. 117-133.

TAVAREs, C. 2011, Praia urbana. Os assentamentos espontâneos. In CunHa, Lúcio e JACINTO, Rui - Interioridades/Insularidades - Despovoamento/Desertificação: 
paisagens, riscos naturais e educação ambiental em Portugal e Cabo Verde. Guarda: CEI, pp. 223-233.

TAGLIONI, F. 2003, Recherches sur les petits espaces insulaires et sur leurs organisations régionales. Paris, Volume II, Mémoire d'habilitation à diriger des recherches. (http://hal.archives-ouvertes.fr/docs/00/04/86/63/PDF/Section_1.pdf)

VeigA, M. 1998, Cabo Verde, Insularidade e literatura. Paris: Karthala.

Vitória, S., Neves, L., Tavares, A. \& Pereira, A. 2011, Modelação da susceptibilidade a cheias através de Sistemas de Informação Geográfica. Um caso de aplicação à região da Praia. In CunHA, Lúcio e JACINTO, Rui - Interioridades/ Insularidades - Despovoamento/Desertificação: paisagens, riscos naturais e educação ambiental em Portugal e Cabo Verde. Guarda: CEI, pp. 191-206.

\section{Fontes Web:}

MINISTÉRIO DE ECONOMIA, CRESCIMENTO E COMPETITIVIDADE - DIREÇÃO GERAL DO TURISMO, Plano Estratégico para o Desenvolvimento do Turismo em Cabo Verde 2010/2013, http://portoncv.gov.cv/dhub/porton.por_global.open_ file?p_doc_id=762

IPDT - Instituto de Turismo, Observatório do Turismo de Cabo Verde: http://www. observatoriodoturismocv.org/pagina.php?id=41

Observatório do turismo: http://www.observatoriodoturismocv.org/multimedia/PLA NO\%20DE\%20MARKETING\%20CABO\%20VERDE\%20-\%202010-2011\%20-\%20 23_07_2010.pdf

Plano de Marketing para o turismo de Cabo Verde: http://www.observatoriodoturis mocv.org/pagina.php?id=89.

Master Plan do Turismo: http://www.ic.cv/InvetExterno.html

INE - Cabo Verde - Contas Nacionais.

INE - Estatísticas do Turismo.

PNUD (2004a), Rapport National sur le Développement Humain Cap Vert -2004, Praia.

MINISTÉRIO DO AMBIENTE, AGRICULTURA E PESCAS GABINETE DE ESTUDOS E PLANEAMENTO. Segundo Plano de Ação Nacional para o Ambiente 
DOCUMENTO SINTESE (2004-2014). VOLUME I: TEXTO PRINCIPAL Praia, Março de 2004. http://www.governo.cv/documents/PANAII-sintese-final.pdf Livro Branco sobre o Estado do Ambiente em Cabo Verde - 2004 (Capítulo sobre Turismo) http://www.sia.cv/documentos/Livrobranco.pdf (Cap. turismo pp. 120 e segs.)

A CONFERENCIA INTERNACIONAL SOBRE EL TURISMO SOSTENIBLE EN PEQUEÑOS ESTADOS INSULARES (PEI) Y OTRAS ISLAS, realizada em Lanzarote (Espanha), http://www.datosdelanzarote.com/Uploads/doc/20051228202649551lanzarote -s.pdf

Sistema de Informação Ambiental (SAI) http://www.sia.cv/index.php?option=com_con tent\&view $=$ article $\&$ id $=88 \&$ Itemid=108\&lang $=$ pt

As regiões ultraperiféricas da União Europeia: Indicadores para caracterizar a ultraperificidade http://www.mcrit.com/rup/documentos/RUP_MEMORIA_ FINAL_POR_def.pdf 